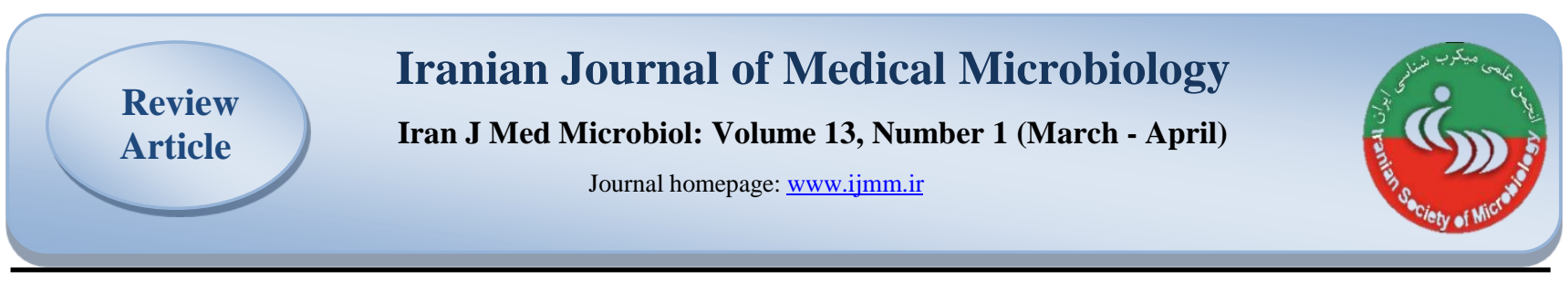

\title{
Psychobiotics and Brain-Gut Microbiota Axis
}

\section{Sima Taheri ${ }^{1}$ (D) Morteza Khomeiri $^{1 *}$}

1. Department of Food Sciences and Technology, Faculty of Food Sciences, Gorgan University of Agricultural Sciences and Natural Resources, Gorgan, Iran

\section{Article Information}

\section{Article Subject: \\ Food Microbiology}

DOI: $10.30699 / \mathrm{ijmm} .13 .1 .1$

Corresponding author:

\section{Morteza Khomeiri}

Department of Food Sciences and

Technology, Faculty od Food

Sciences, Gorgan University of Agricultural Sciences and Natural

Resources, Gorgan, Iran

Email:

\section{khomeiri@gau.ac.ir}

Use your device to scan and read the article online

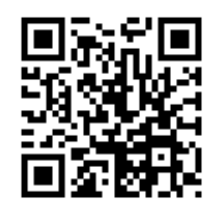

\section{Abstract}

Fermented foods containing probiotic bacteria have been used for many years to improve the health or treatment of some diseases. Nowadays, the Therapeutic properties of probiotics are becoming more and more obvious to everyone, insofar as in recent years, more attention has been paid to the potential relation between gut microbiota and mental health. Several studies have shown that intestinal microbiota play some roles in development and function of brain as well as psychiatric parameters such as sleep, appetite, mood and perception through production of active neural molecules. These findings, in turn had led to further research on new therapies for the resolution of mental disorders through changing and modification of intestinal microflora using a new therapeutic group called psychobiotics. Psychobiotics are probiotic bacteria that if consumed in adequate dosage, affect the function of the intestines and brain and reduce the symptoms of psychiatric illness.

Keywords: Psychobiotic, Intestinal microflora, Neuropsychiatric disease, Probiotic food
Received: 2019/01/15 Accepted: 2019/06/02 Available online: 2019/06/20

Copyright $\odot 2019$ Iranian Journal of Medical Microbiology. This is an open-access article distributed under the terms of the Creative Commons Attribution License (http://creativecommons.org/licenses/by/4.0), which permits unrestricted use, distribution, and reproduction in any medium, provided the original work is properly cited.

How to cite this article:

Taheri S, Khomeiri M. Psychobiotics and brain-gut microbial axis. Iran J Med Microbiol. 2019; $13(1): 1-13$ 
مجله ميكروبشناسى يزشكى ايران

سال س| - شماره | - فروردين و ارديبهشت ^ه؟ा

Journal homepage: www.ijmm.ir
مقاله

مرورى

\section{سايكوبيوتيكها و محور ميكروبى مغز-روده}

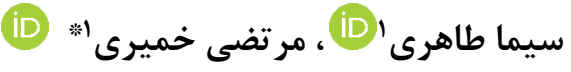

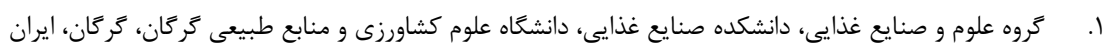

\section{جكيلده}

در كذشته مردم براى بهبود سلامتى و يا درمان برخى از بيمارىها از مواد غذايى تخميرى كه حاوى باكترىهاى يروبيوتيك ديك

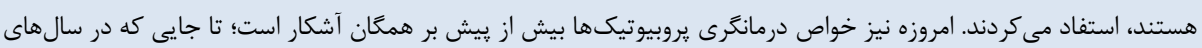

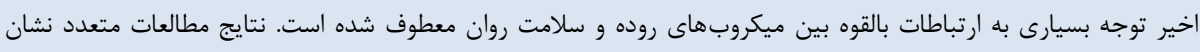

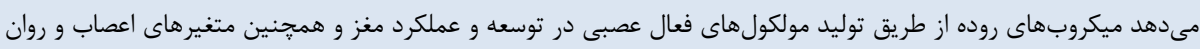

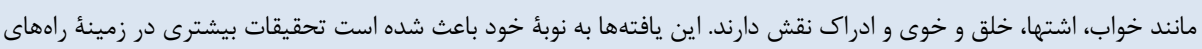

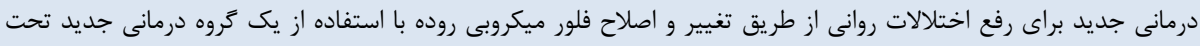

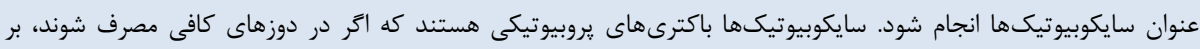

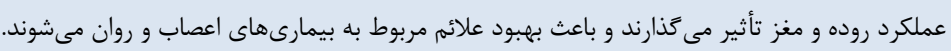
كلمات كليدى: سايكوبيوتيك، فلور ميكروبى روده، بيمارى اعصاب و روان، مواد غذايى يروبيوتيك نويسندهُ مسئول: مر تضى خميرى دانشيار كروه علوم و صنايع غذايى، ميكروبيولوزى مواد غذايى، دانشكده صنايع غذايى، دانشَاه علوم كشاورزى و منابع طبيعى إنى

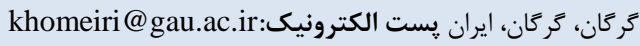
كيىرايت () مجله ميكروبشناسى بزشكى ايران: دسترسى آزاد؛ كيىبردارى، توزيع و نشر براى استفاده غيرتجارى با ذكر منبع آزاد
اطلاعات مقاله

تاريخجٌهُ مقاله

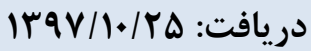

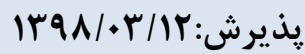

انتشار آنلاين: • بـ/

موضوع:

ميكروبيولوزى مواد غذايى

IJMM1398;13(1): 01-13

مقدمه

اگر دل را مصداق تعبير اول فرض كنيه، بايد كفت كه رفتار، مزاج و احساسات ما تحت تأثير عوامل اصلى موجود در اين بخش است كه از مهمترين آنها مىتوان به حضور عوامل ميكروبى اشاره كرد.

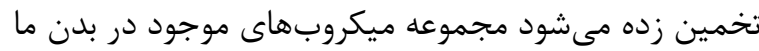

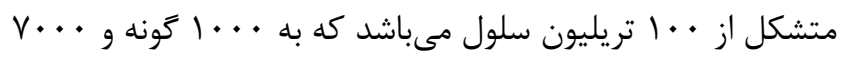

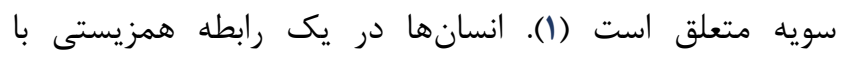
ميكروبهاى روده زندگى مى كنند. ما منابع ثابتى از مواد غذايى را

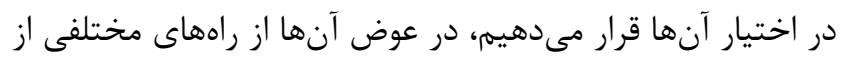

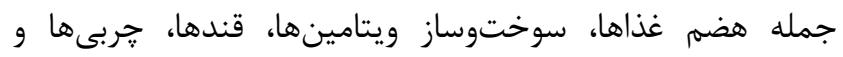
آمينواسيدها، و تقويت سيستم ايمنى بدن، از ما در برابر باكترىهاى سماى

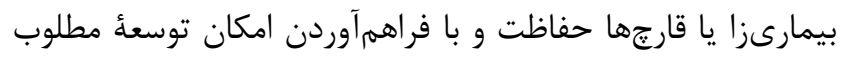
مغز و عملكردهاى بعدى به ما كمك مئى كنند (ه- (؟). عوامل
تمامى افراد در طول زندگى در شرايطى قرار مى گيرند كه مى تواند منجر به احساس ترس، خوشحالى، هيجان، استرس، افسردگى و غيره گردد يا ممكن است به هنگَام گرسنگى رفتارشان تغيير كند؛ به عنوان مثال عصبانى شوند يا تمركز خود را در كار از دست بدهند. قسمت سفيد مغز در شرايط مختلف، احساسات، تفكرات و رفتار ما

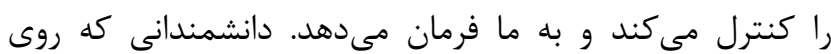

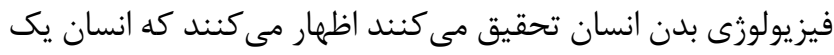

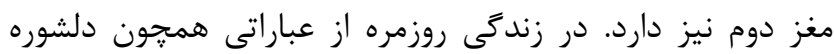

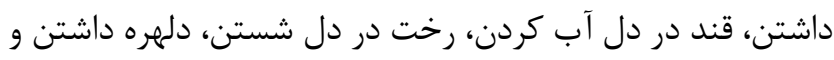

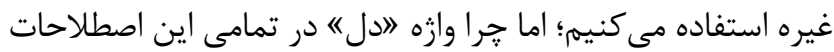

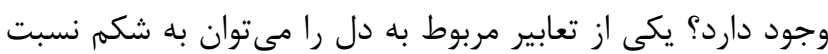

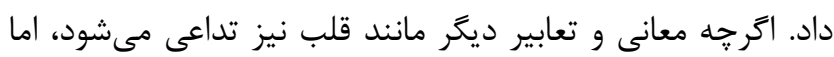


راستاى افزايش قابليت زندهمانى باكترىهاى يروبيوتيك در مخلوط

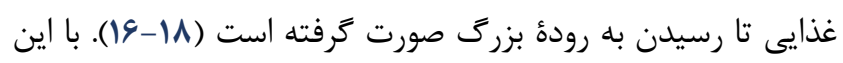

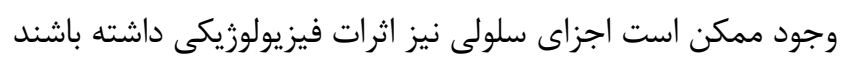
كه مىتواند در ارتقاى سلامت فرد مؤثر باشد (19).

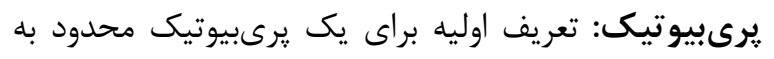

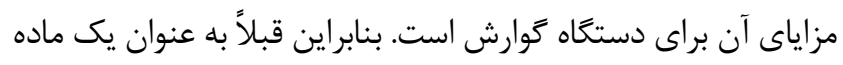

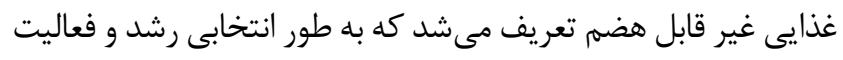

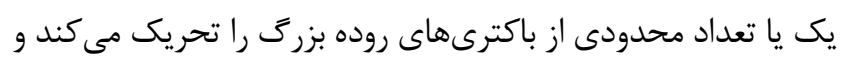

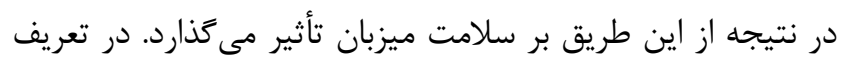

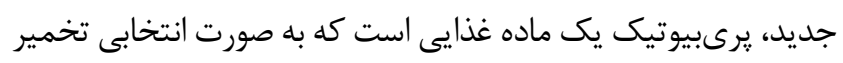

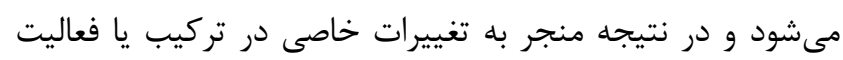

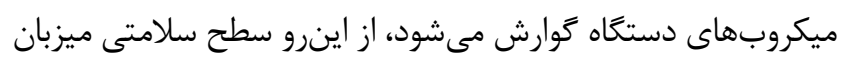
را ارتقا مى دهد (•r).

يُستبيوتيك: پِستبيوتيكها به محصولات يا متابوليتهاى

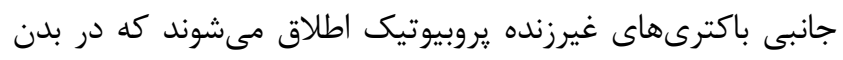

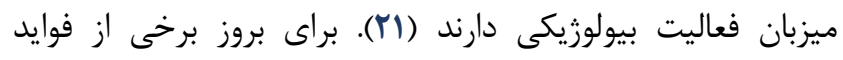

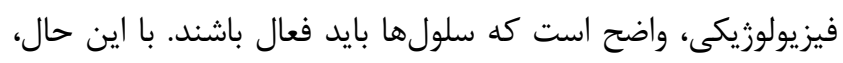

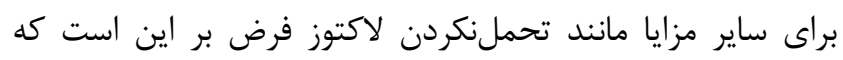

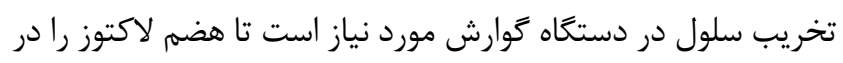

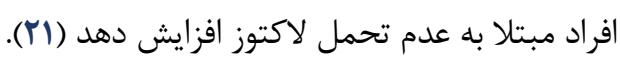

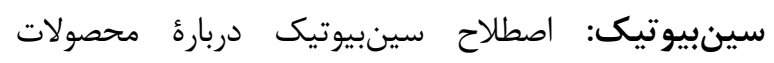
غذايىاى بيان مىشود كه تركيبى از برىبيوتيكها و يروبيوتيكهات إنها

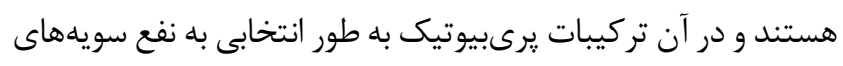

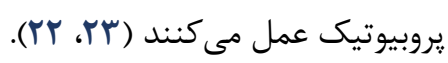

\section{سايكوبيوتيك: سايكوبيوتيك را مىتوان ميكرواركانيسم}

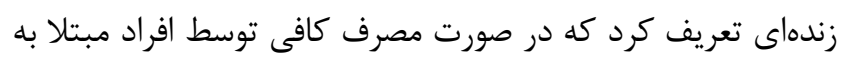

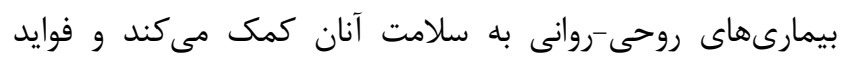

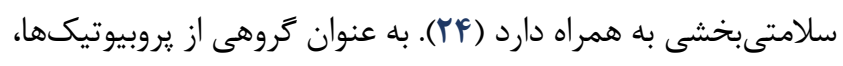

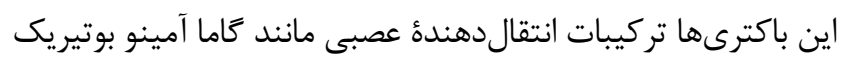
اسيد توليد مى كنند كه در محور ميكروبى مغز -روده فعال هستند.

\section{محور ميكروبى مغز -روده (Brain-Gut-Microbiota Axis)} بين مغز و روده ارتباط مستمرى وجود داردود مارد. اين تعامل

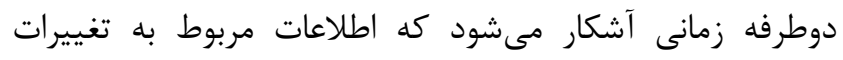

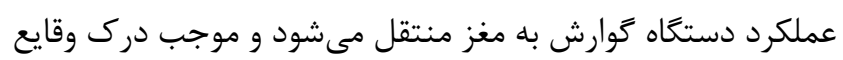

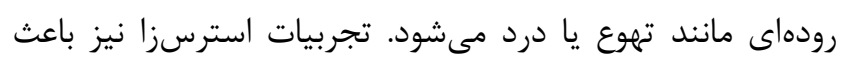

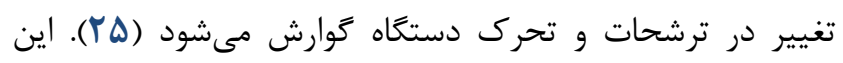

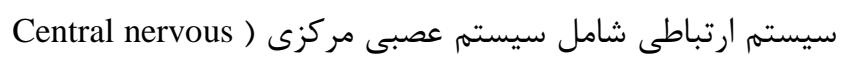

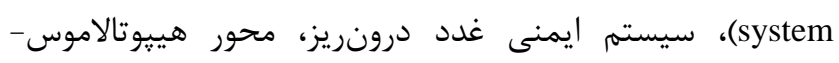

متعددى مانند زنتيك، رزيم غذايى، عفونت، مصرف دارو، سن و مائ ماندي

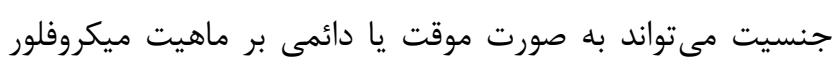

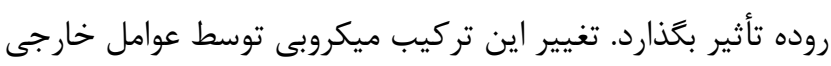

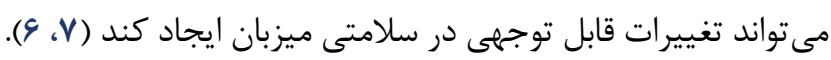

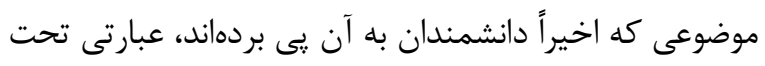

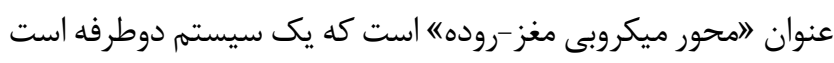

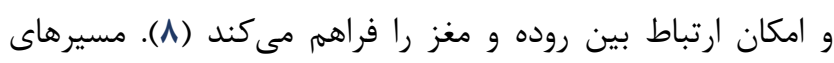

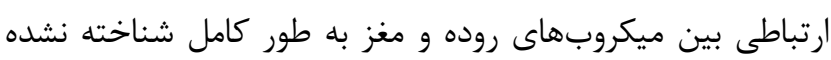

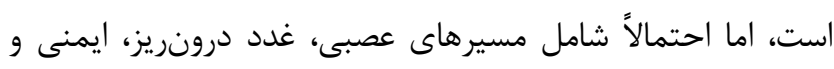

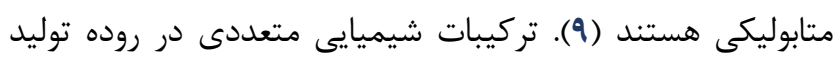

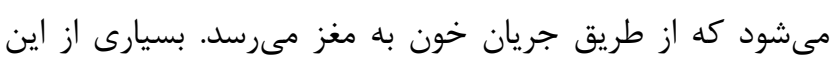

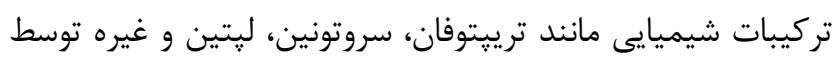

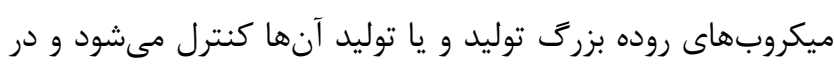

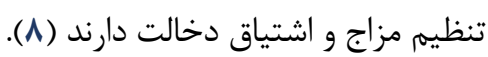
در دهأ كذشته، تحقيقات بيشترى در زمينأ امكان هدف

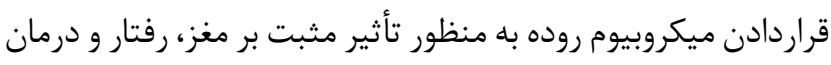

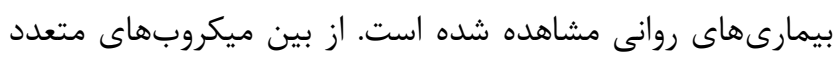

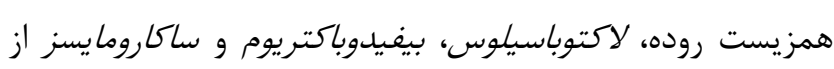

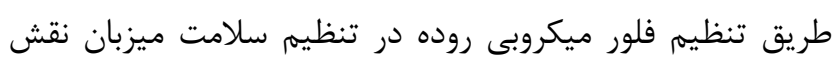
دارند (•(). اين باكترىهاى مفيد كه به طور مرسوم تحت عنوان

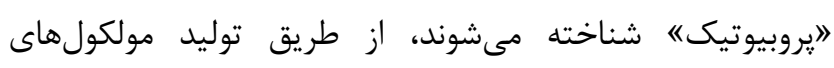

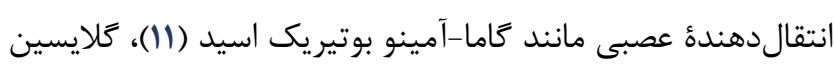

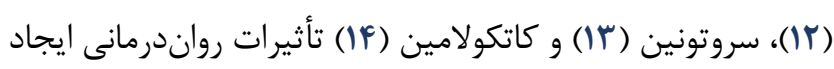

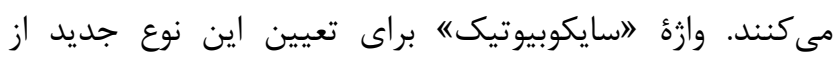

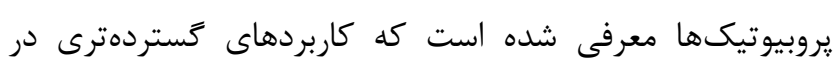

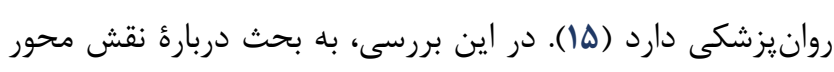

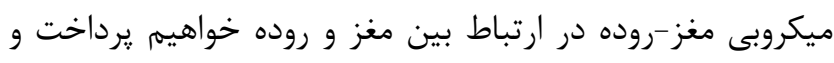

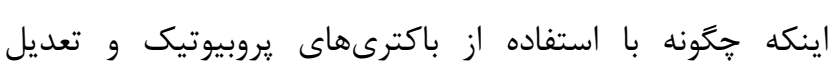

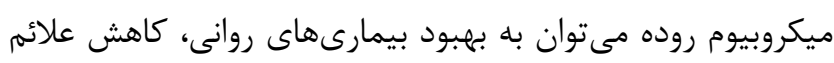

$$
\text { استرس و اضطراب كمك كرد. }
$$$$
\text { تعاريف }
$$

يروبيوتيك: تعريف يروبيوتيك در طول زمان جندين بار

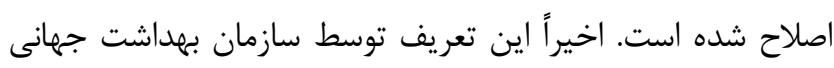

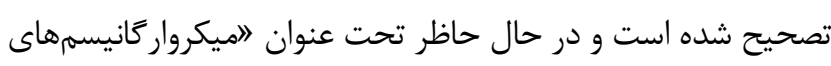

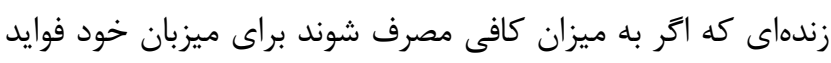

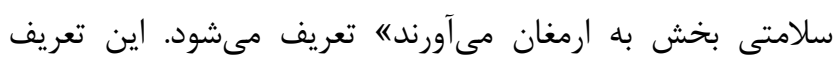

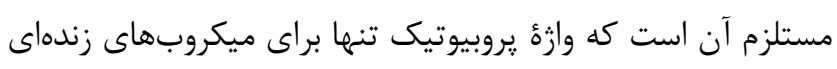

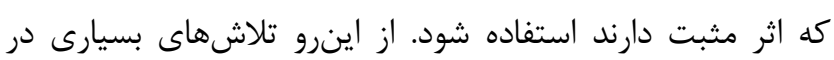


رابطه دو طرفه بين روده و عملكرد مغز زمانى آشكار مى شود كه در

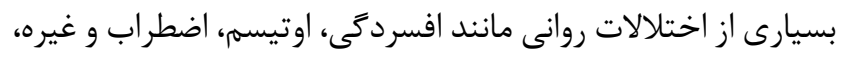
فلور ميكروبى روده تغيير مى كند (Y) (Y).

\section{سندروم خستكى مزمن و فيبروميالزيا}

(Chronic Fatigue Syndrome and Fibromyalgia)

سندروم خستخى مزمن به خستَى عمومى بدن كَفته مى شود

كه به مدت طولانى ادامه داشته باشد. اين خستخى در در تمام بدن

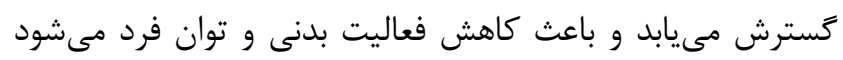

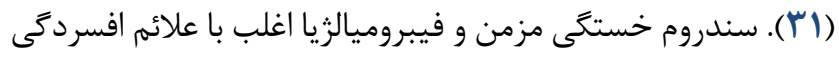

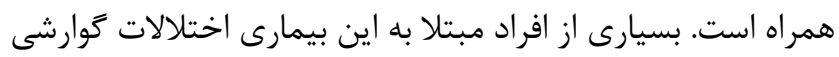

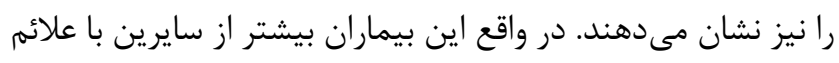

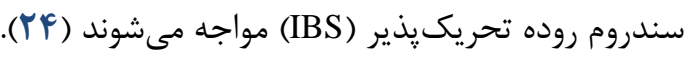

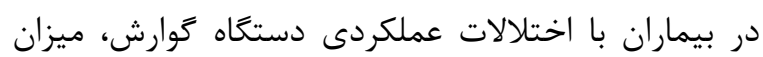

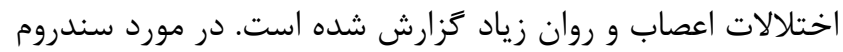

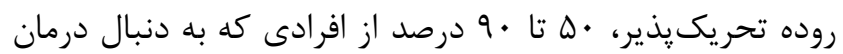

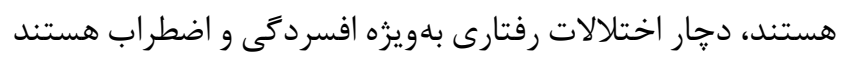

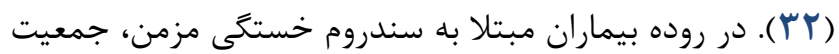
لاكتوباسيلوس و بيفيدوباكتريوم و نيز نسبت باكترى هاى بى هوازى دينى به هوازى كاهش مى يابد (Tr). اكر جه مكانيسمهاى دخيل در اين

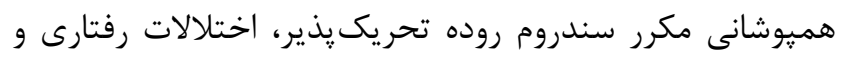

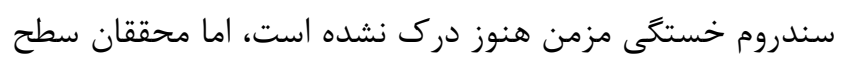

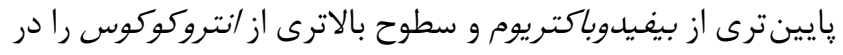

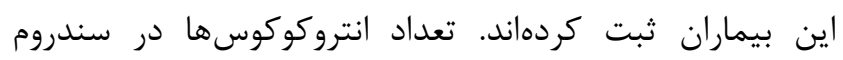

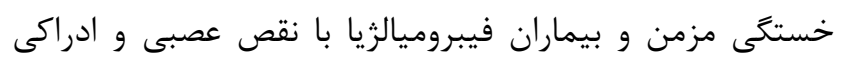

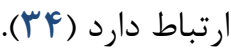

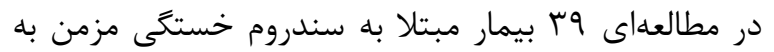

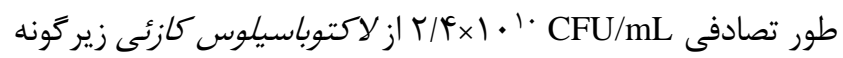

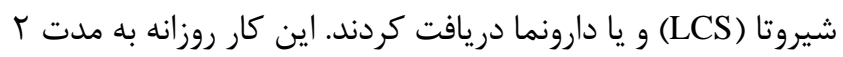

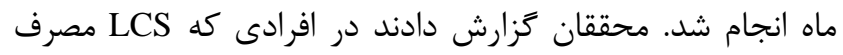

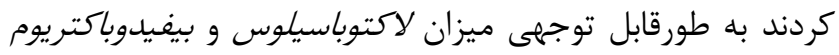

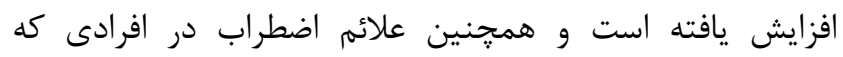
يروبيوتيك مصرف كردند نسبت به افرادى كه دارونما مصرف كردند به طور معنى دارى كمتر شد (ه山). اين مطالعات ارتباط حياتى بين

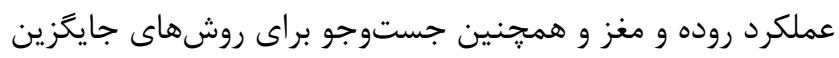
درمانى اختلالات روانى را تقويت مى كند.
هييوفيز-فوق كليه (Hypothalamus-pituitary-adrenal axis)،

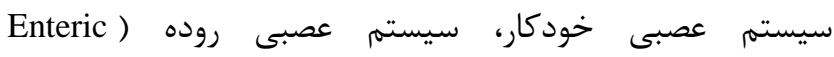

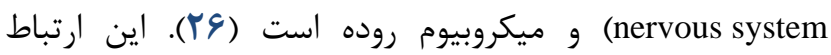
دوطرفه، امكان ايجاد سيخنال هاى مغزى از طرف مغز ران ران فراهم مى كند تا شرايط حركتى، حسى و ترشحى دستخاه گوارش را تحت إنى

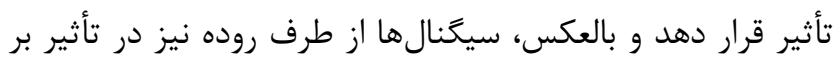

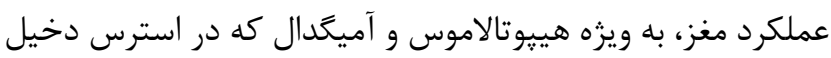

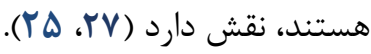
مطالعات جندين گروه تحقيقاتى در كانادا، ايرلند و سوئد نشان

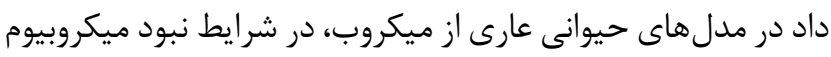

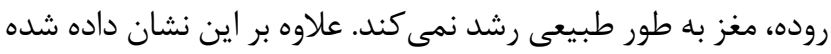
است فرايندهاى اساسى مغز مانند ميليناسيون (Myelination)، نوروزنزيس (Neurogenesis) در بزر كسالان و فعال سازى ميكروكليا نيز بهشدت به تركيب ميكروبى روده (Microglial activation) وابسته است (ه)). (1) (1) . . ميليون نورون در روده ما وجود دارد كه به واسطه ترشح

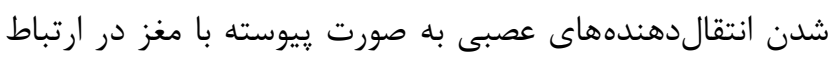

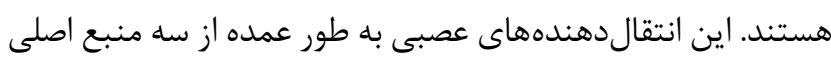
ترشح مىشوند: نورونها در مغز، سلولهاى انتروكرومافين (نnرونهاى تخصصى در ديوارؤ روده) (Enterochromaffin Cells)

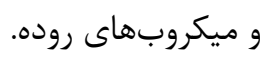
حدود 1 أ ـا ميكروار كانيسم به طور طبيعى در روده ما ساكن

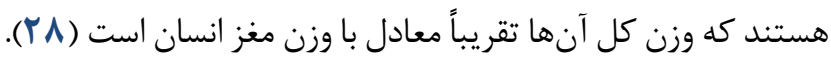
بسيارى از اين باكترىها قادر به توليد تركيبات فعال عصبى هستند

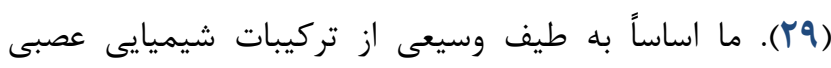

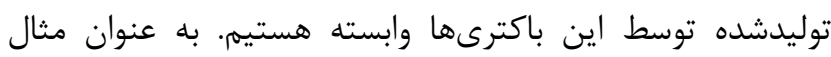
سيستم سروتونرزيك مغز كه نقش كليدى در فعاليتهاى عاطفى ايفا مى كند، در غياب باكترىها بهخوبى توسعه نمىيابد (•"ّ).

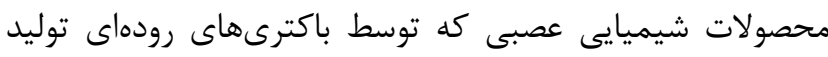

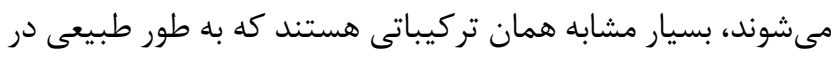

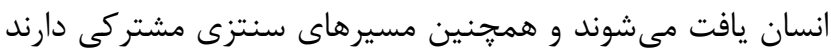

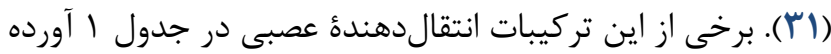

\section{نقش باكترىهاى روده در بيمارىهاى اعصاب و روان}

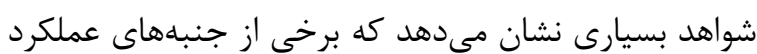

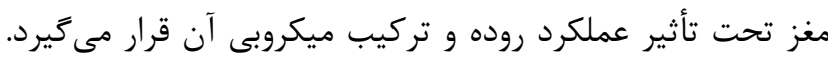


جدول ا. برخى از انتقال دهندهاى عصبى توليدشده به واسطه باكترىهاى روده

\begin{tabular}{|c|c|c|c|c|c|c|}
\hline 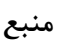 & 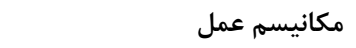 & تركيب نهايى & تركيب اوليه & آنزيم توليدى & 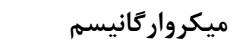 & انتقال دهندهٔ عصبى \\
\hline$(\wedge \vee)$ & كاهش فعاليت سيستم عصبى و كاهش سطح استرس و & $\begin{array}{l}\text { Free } \\
\text { catecholamines, } \\
\text { Noradrenaline } \\
\text { Dopamine }\end{array}$ & $\begin{array}{l}\text { Glucuroconjugated } \\
\text { catecholamines }\end{array}$ & $\begin{array}{l}\text { Beta- } \\
\text { glucuronidase }\end{array}$ & $\begin{array}{l}\text { Escherichia } \\
\text { Bacillus } \\
\text { Serratia } \\
\text { Clostridium }\end{array}$ & Catecholamines \\
\hline (11) & و اضطرابزا، اثر مثبت دردى سطح رفتارهاى انخَيزه & GABA & $\begin{array}{l}\text { Monosodium } \\
\text { glutamate }\end{array}$ & $\begin{array}{l}\text { Glutamate } \\
\text { decarboxylase }\end{array}$ & $\begin{array}{l}\text { Lactobacillus } \\
\text { brevis } \\
\text { Lactobacillus } \\
\text { rhamnosus } \\
\text { Bifidobacterium } \\
\text { dentium } \\
\text { Bacteroides } \\
\text { fragilis } \\
\text { Dorea } \\
\text { longicatena }\end{array}$ & $\begin{array}{r}\gamma \text {-aminobutiric } \\
\text { acid }\end{array}$ \\
\hline \multirow[t]{2}{*}{$(1 T)$} & \multirow[t]{2}{*}{ تنظيم خواب، افزايش لذت و آرامش } & Serotonin & Tryptophan & $\begin{array}{l}\text { Tryptophan } \\
\text { hidroxylase }\end{array}$ & $\begin{array}{l}\text { Escherichia } \\
\text { Streptococcus } \\
\text { Clostridium } \\
\text { sporogenes } \\
\text { Enterococcus }\end{array}$ & \multirow[t]{2}{*}{ Serotonin } \\
\hline & & Serotonin & \multicolumn{2}{|c|}{ ترشح سروتونين از سلولهاز ترب زنجير انتروكروماهو و تحرين } & $\begin{array}{l}\text { Anaerobic } \\
\text { fermentative } \\
\text { bacteria }\end{array}$ & \\
\hline (AV) & تقريك آزادسازى سروتونين و & Tryptamine & Tryptophan & $\begin{array}{l}\text { Tryptophan } \\
\text { decarboxylase }\end{array}$ & $\begin{array}{l}\text { Clostridium } \\
\text { Sporogenes } \\
\text { Ruminococcus } \\
\text { Gnavus }\end{array}$ & Tryptamine \\
\hline
\end{tabular}

تأييد مى كند. درمان با ونكومايسين به مدت 1 هفته باعث بهبود رفتار در ^ كودى از • ا كودك تحت درمان شد. متأسفانه اين تأثير

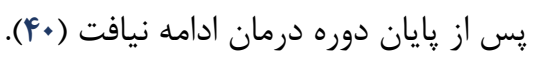
مدفوع افراد مبتلا به ASD در مقايسه با كودكان سالم حاوى مقادير بيشترى از باكترىهاى كروه كلستريديوم هيستوليتيكوم

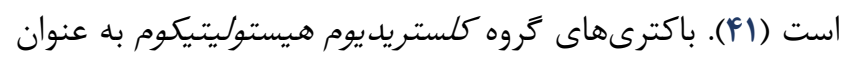
توليدكنند

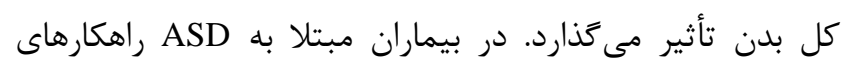
كاهش سطح كلستريديوم و يا بهبود وضعيت فلورميكروبى روده از طريق تعديل رزيم غذايى ممكن است به كاهش اختلالات روده

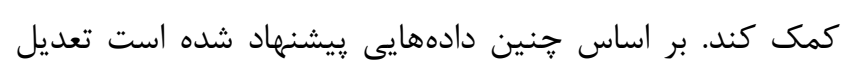
جمعيت ميكروبى روده بيماران ASD از طريق كاهش تعداد كلستريديوم و در عين حال تحريك باكترىهاى مفيد روده مىتواند به كاهش برخى علائم عصبى كمك كند. به كاركيرى يروبيوتيكها

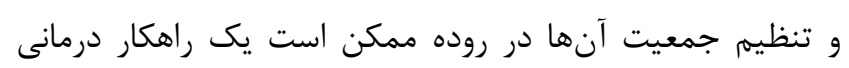

\section{اختلال طيف اوتيسم (Autism Spectrum Disorder)}

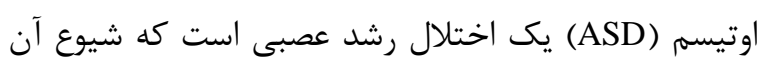
رو به افزايش است و با نداشتن توانايى در زبانآموزى، ويزگى ئى

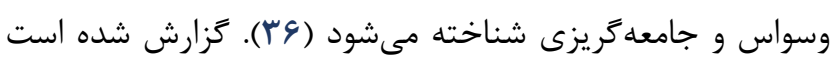
كه كودكان مبتلا به اوتيسهم اغلب مشكلات توارشى دارند. جنـدين مورد رزيم غذايى محدود (مانند رزيمهاى غذايى بدون كلوتن يا

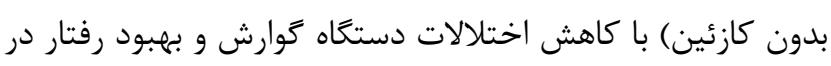

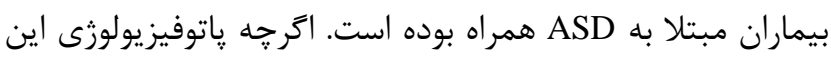
بيمارى تاحدودى نامشخص باقى مانده است، اما به نظر ميىرسد

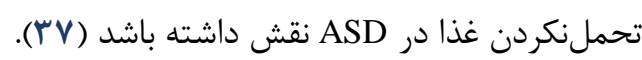
بيماران ASD و بستخان درجه اول آنها سلولهاى سطحى

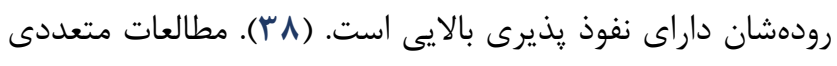

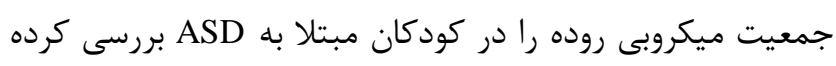
است. نتايج نشان مى دهد تركيب ميكروبى در نمونههاى مدفوع و

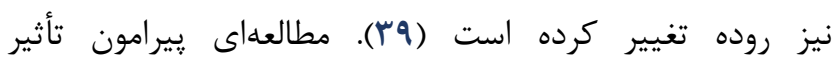

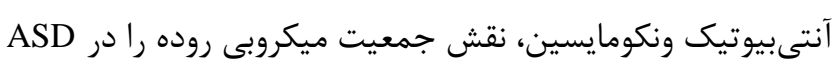


حاوى مقادير زياد اليكو يا مونوساكاريدهايى كه بلهادگى تخمير

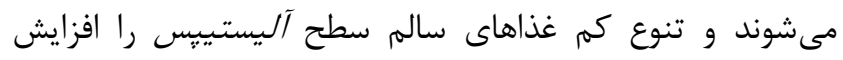
مى دهد (FV). كاهش سطح /سيلى باكتر در معده و روده نيز با افسردگى

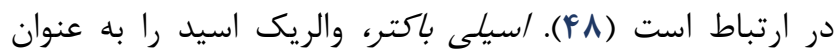

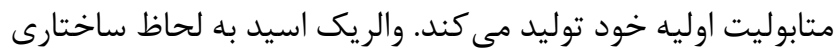
مشابه Gamma-Aminobutyric acid) GABA) است و مى تواند به كيرنده آن متصل شود. بنابراين، ممكن است باكترىهايى كه

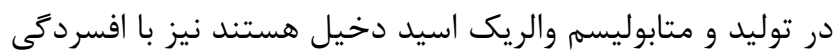
مرتبط باشند (ه) (ه). سوء جذب لاكتوز حالت بسيار شايعى است كه با كمبود لاكتاز

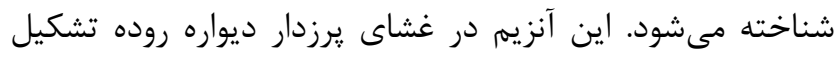

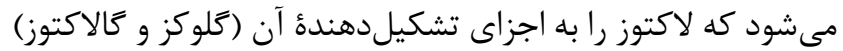

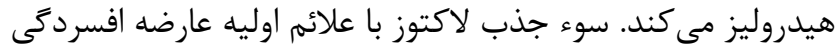
در زنان همراه است (AT). غلظت بالاى لاكتوز در روده ممكن است

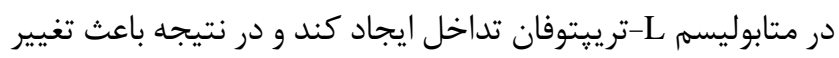

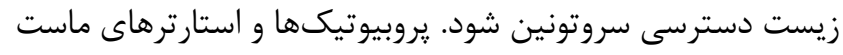

به بهبود هضم لاكتوز كمك مى كنند (UT).

افسردگى با كمبود مواد مغذى نيز مى تواند تشديد شود، زيرا

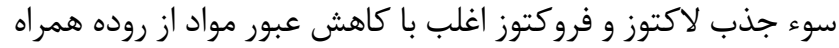
است و منجر به كمبود ويتامين مى شود. فراوانى افسردكى در افر افرادى كه سوء جذب فروكتوز دارند بيشتر است (QF). بيماران مبتلا به

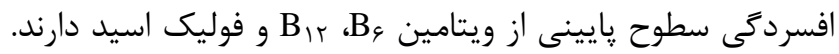

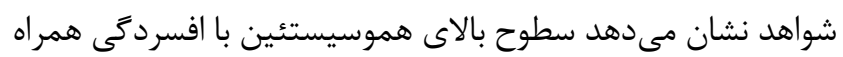

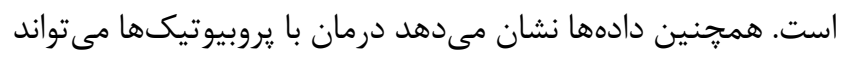
سطح هموسيستئين را در انسان كاهش دهد (هان دهان. تحقيقات بيان كردهاند كه مخلوط بروبيوتيكى بيفيدوباكتريوم

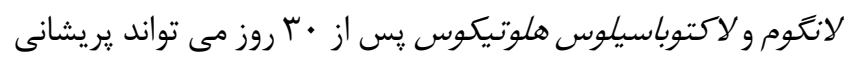

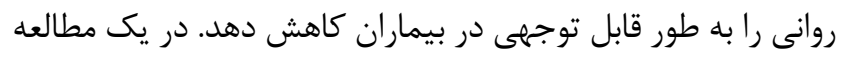

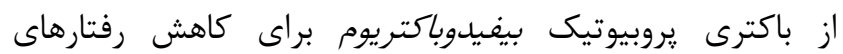

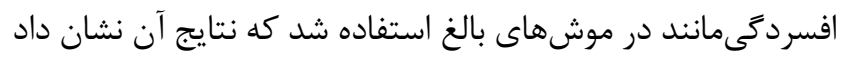

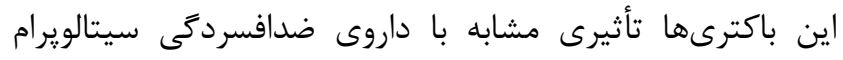
(Citalopram)

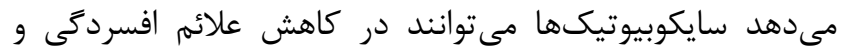

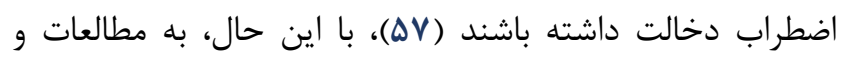
بررسىهاى بيشترى در اين زمينه نياز است.
اميدواركننده باشد. با اين حال، هيجَّونه آزمايش بالينى دال بر اين قضيه منتشر نشده است.

\section{بيمارى ياركينسون (Parkinson's Disease)} بيمارى پاركينسون (PD) يك اختلال درازمدت سيستم عصبى مركزى است كه عمدتاً سيستم حركتى را تحت تأثير قرار

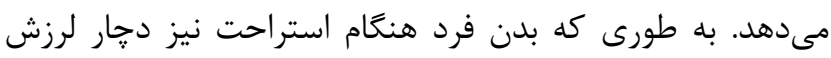

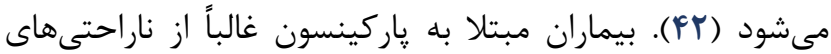

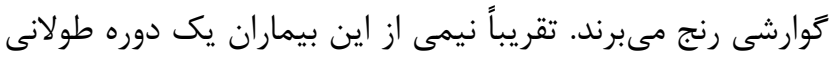

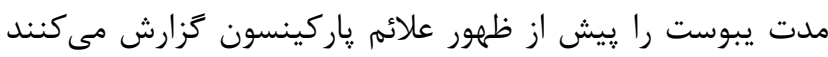

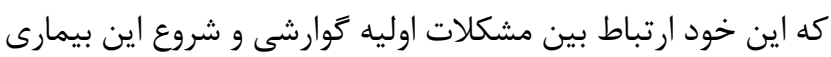

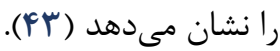

مشخصه پاتوبيولوزيكى PD وجود يروتئين آلفا-سينوكلين در بافت هاى عصبى است. ظهور اين تركيب در اعصاب روده منجر به اين فرض شد كه ممكن است روده در پاسخ به يك سم يا ياتورثن محيطى با PD در ارتباط باشد و نفوذيذيرى روده افزايش يابد. به

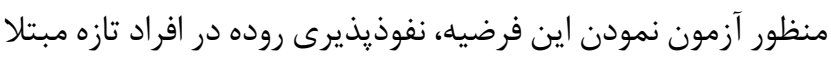
شده به PD را مورد بررسى قرار دادند و با افراد سالم مقايسه كردند.

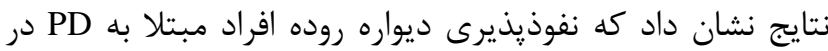

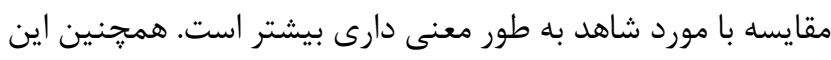

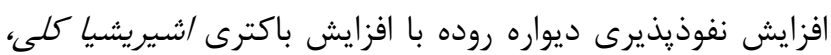
نيتروتيروزين و آلفا-سينوكلين در مخاط روده ارتباط معنى دارى

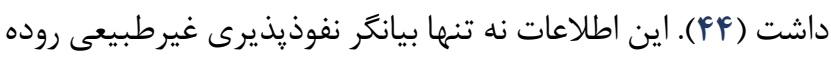

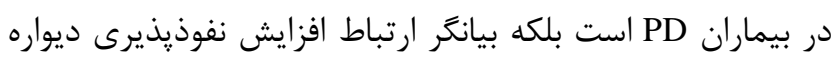

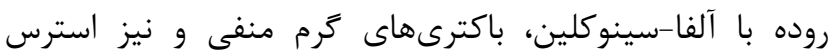

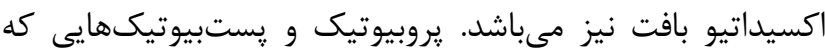

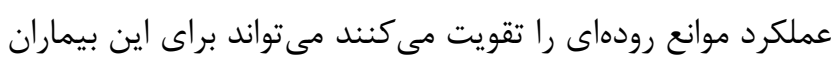

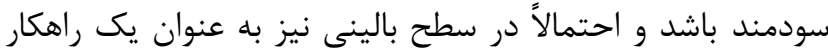

$$
\text { درمانى در نظر گرفته شود. }
$$

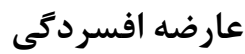

ارتباط بين استرس، جمعيت ميكروبى و خلق و خوى افرى افراد زمينه تحقيقاتى مهمى است. در يك مطاله كه در آن موشهاى

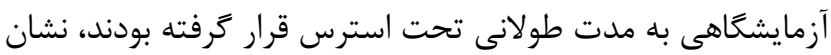

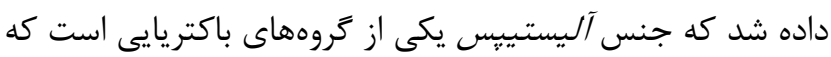

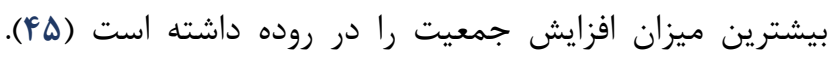

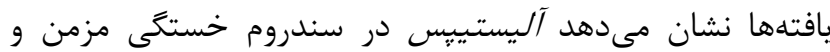

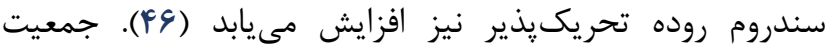

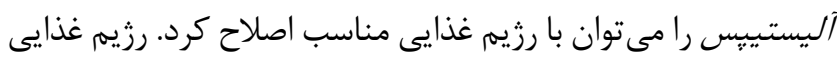


براى درمان عفونت مكرر كلستريديوم ديفيسيل مورد توجه و علاقه

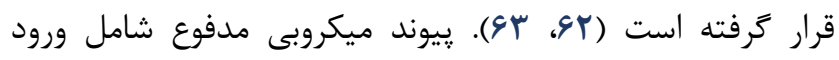

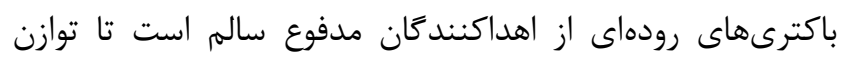

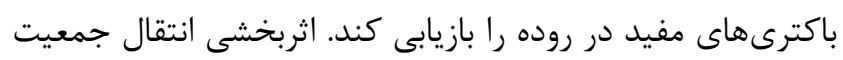

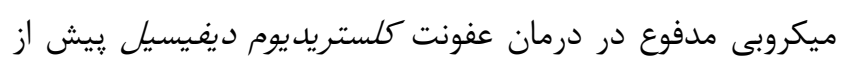

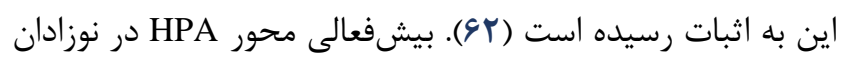

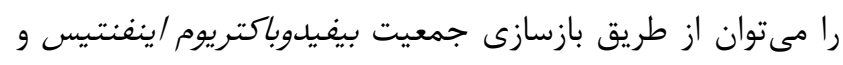

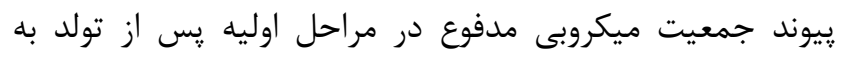

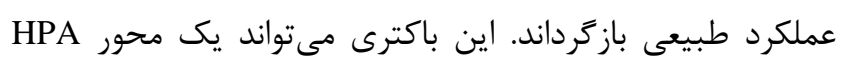

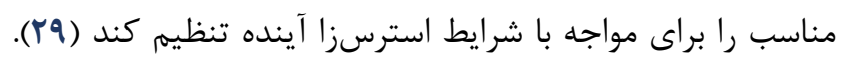

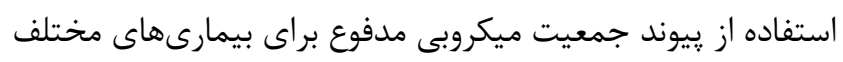

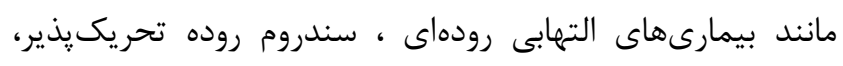

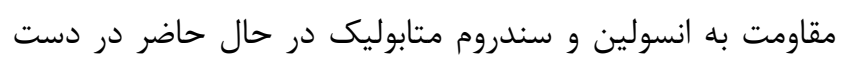

$$
\text { بر برى است. }
$$

\section{جَكَونه مى توانيم ميكروبيوم خود را خودمان بهينه كنيم؟}

\section{مصرف مكمل هاى سايكوبيوتيك}

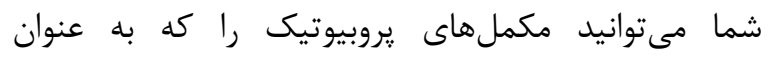
سايكوبيوتيك واجد شرايط هستند، مصرف كنيد. اما يِيدا كردن

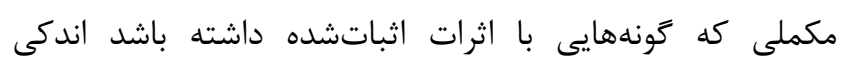

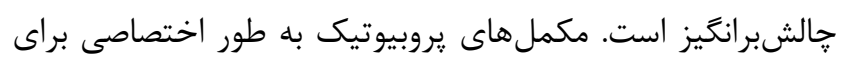

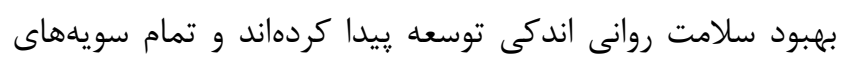

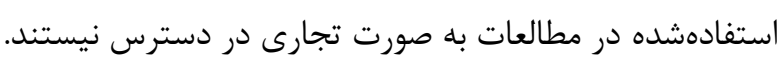

\section{مصرف مكمل بروبيوتيك براى سلامت عمومى ند}

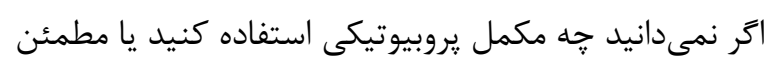

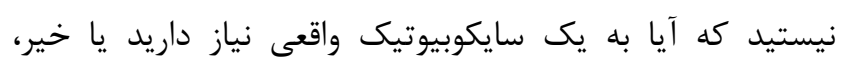

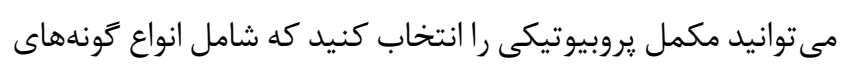

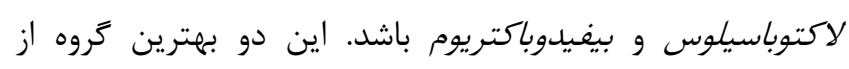

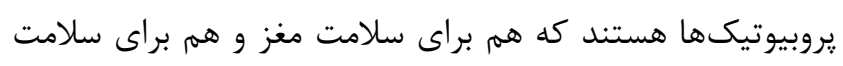

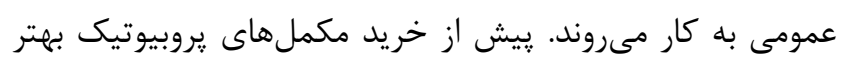

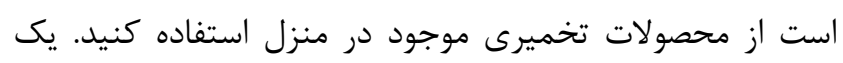

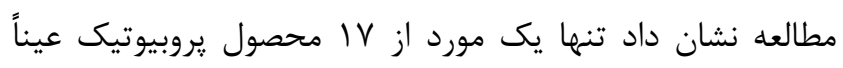
مطابق با محتواى خود برجسب تُذارى شده است.

\section{مصرف غذاهاى يروبيوتيك}

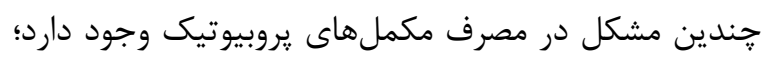

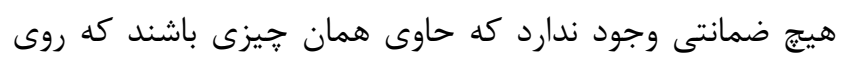
برجسب ذكر شده است. هيج ضمانتى مبنى بر زنده ندارد ماند هاندن اين

\section{مكانيسم عمل سايكوبيوتيكها}

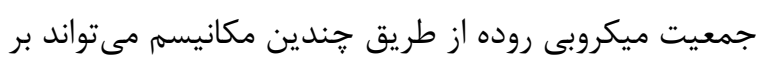

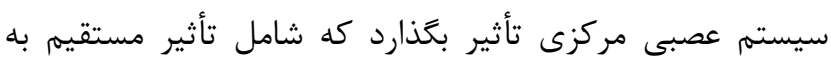

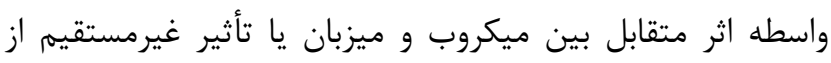

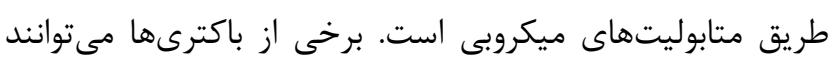
عصب واگوس (Vagus nerve) را مستقيماً فعال كنند (ه1).

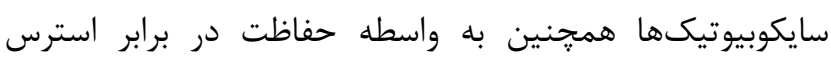

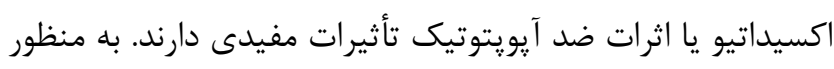

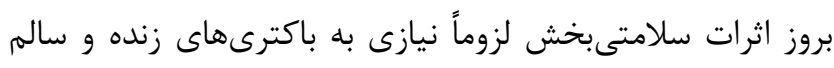

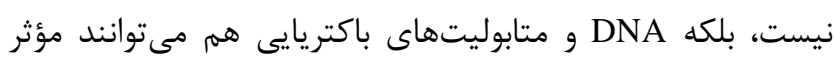

باشند (ه9).

اثرات يروبيوتيكى به سويه وابسته است و هر نوع سويهاى براى

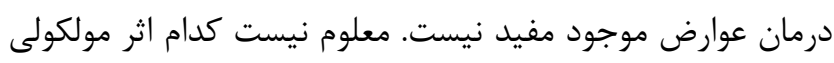

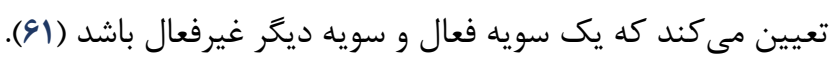

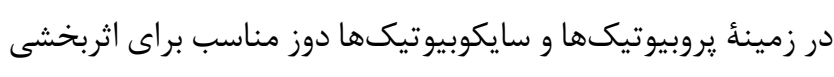

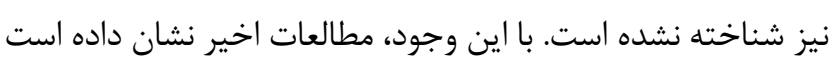
يك ميزان مطلوب بايد وجود داشته باشد (•و).

\section{Fecal Microbiota ( ييوند جمعيت ميكروبى مدفوع}

(Transplantation

و و همكاران (rا • Collins

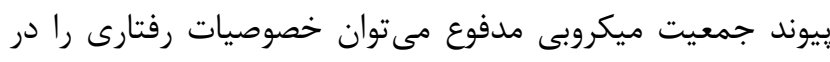

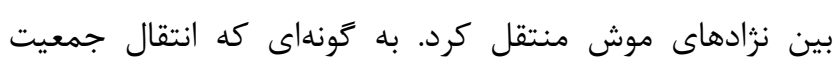

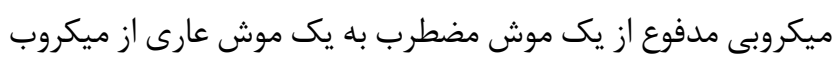

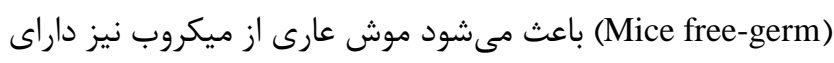

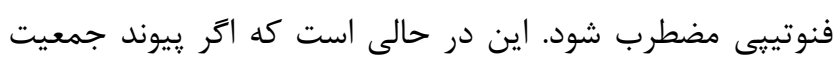

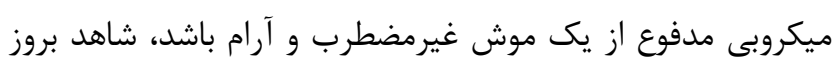

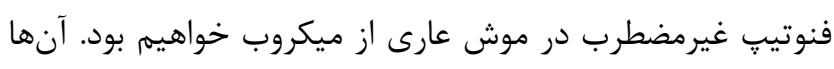

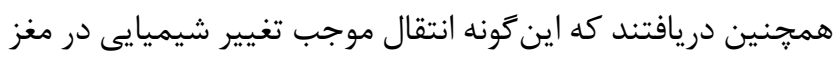

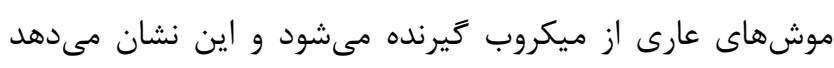

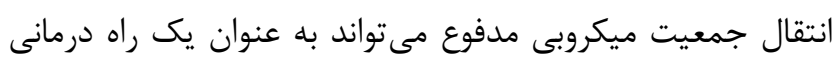

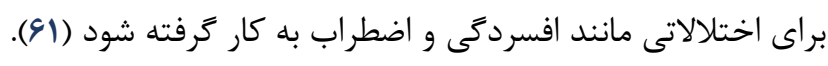
استفاده از مخلوطى از كَنههاى انتخابشده باكترىهاى مفيد

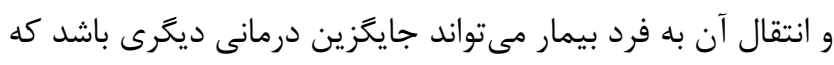

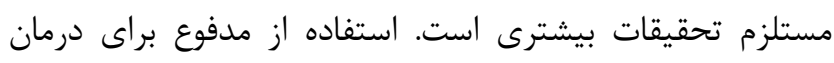

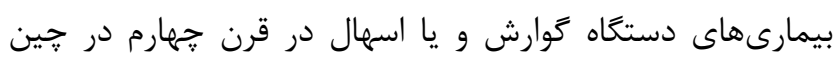

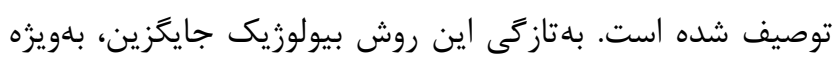


فر آوردههاى لبنى تخميرى حاملى مناسب براى تحويل

\section{باكترىهاى سايكوبيوتيك ل}

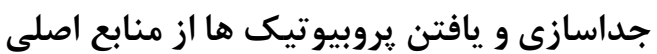

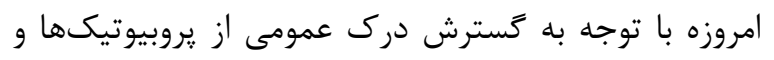

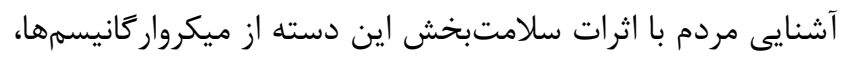
محصولات لبنى تخميرى سنتى مانند ماست، كفير، كوميس، دوغ

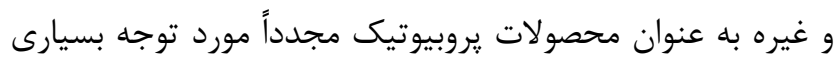

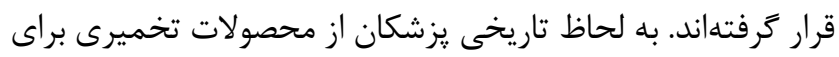
درمان بسيارى از بيمارىها مانند مشكلات توارشى، فشارخون بالا تران

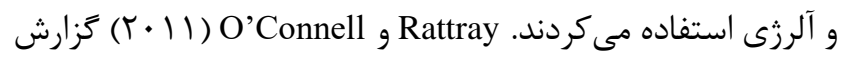
دادند كه مصرف كفير ممكن است تركيب جمعيت ميكروبى روده إند را از طريق مهار مستقيم پاتوزنها تغيير دهد؛ به طورى كه اجازه

جسبيدن ياتوزنها به ديواره روده را ندهد (SV)

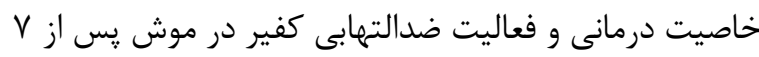

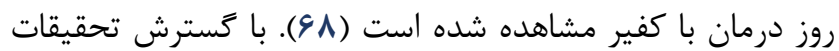
در زمينه محصولات لبنى يروبيوتيك محققان مختلفى كزارش داده

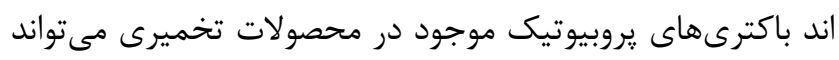

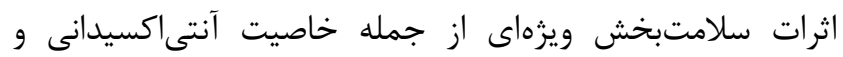

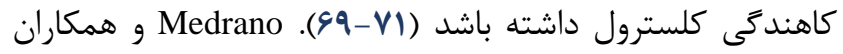

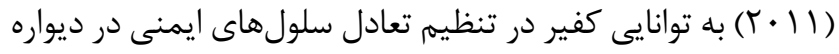

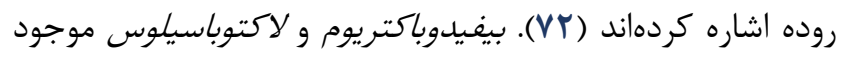
در محصولات تخميرى لبنى توانايى زيادى در توليد ترييتوفان دارند

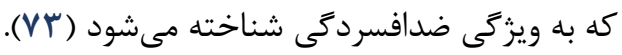

بر اين اساس دستهاى از تحقيقات به دنبال يافتن يروبيوتيك هاى داراى ويزگى طبيعى خاص هستند كه از طريق جداسازى و

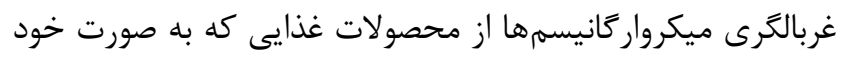

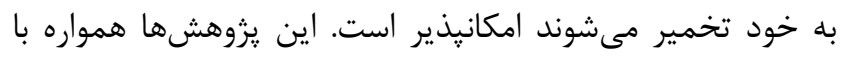

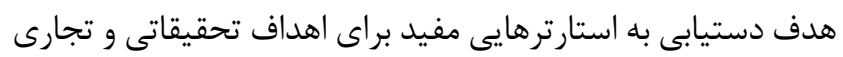
به انجام مى رسند. در مطالعات بسيارى باكترىهاى اسيدلاكتيك از

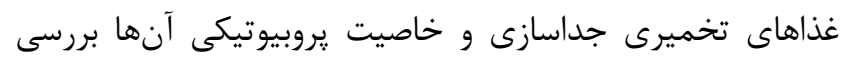

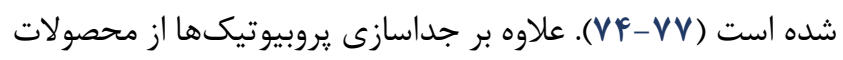
تخميرى سنتى، جون بسيارى از باكترىهاى يروبيوتيك مورد توجه

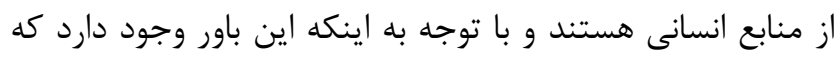

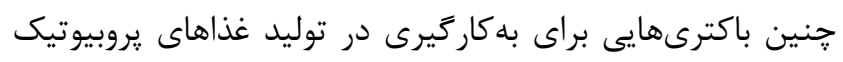
انسانى مناسبتر هستند، جداسازى باكترى هاى يروبيوتيك از انسان از جمله اقداماتى بوده است كه در اين راستا انجام شده است (Tr-
باكترىها در حين عبور از شرايط اسيدى معده و روده وجود ندارد

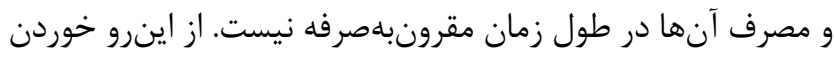

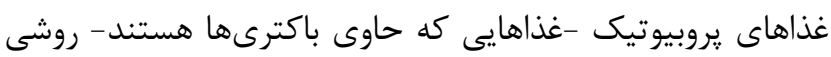
مناسب براى افزايش باكترىهاى مفيد روده است. تقريباً تمام

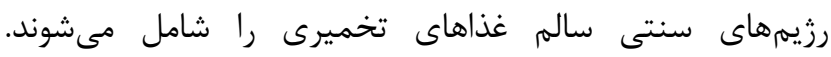

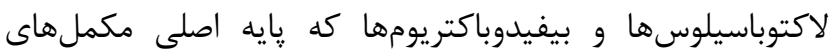

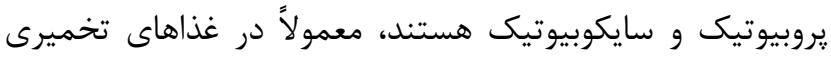
يافت مىشوند (بَو). با افزودن اين مواد غذايى (ماست، كفير،

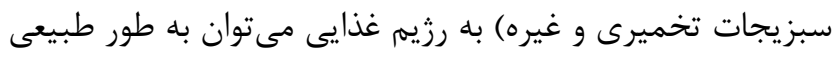
فلور ميكروبى مفيد رود را تقويت كرد.

\section{مصرف غذاهاى يرىبيوتيك}

يرىبيوتيكها غذاى يروبيوتيكها هستند كه براى رشد به به به

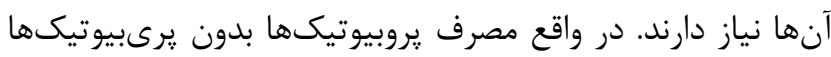

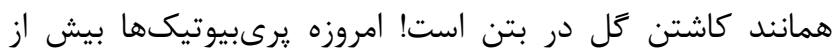

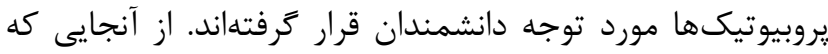

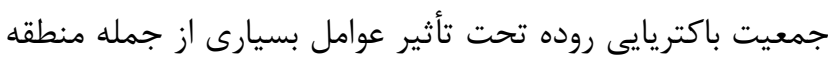
جغرافيايى است و هر فرد يروبيوتيكهاى خاص خود راسي را دارد، توصيه

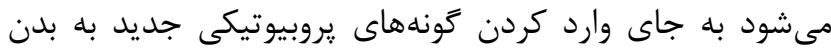

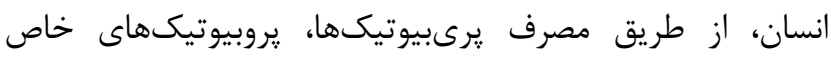
دستخاه كوارش آن فرد توسعه داده شود (\$\&).

\section{بازى كردن با خاك}

تمام باكترىهاى مفيد را نمىتوان از طريق دهان وارد بدن

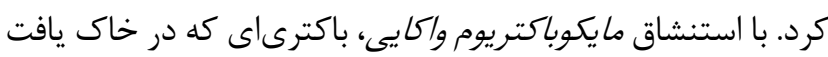

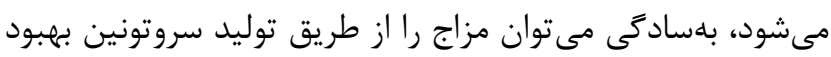

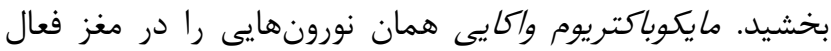

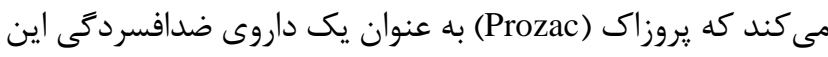

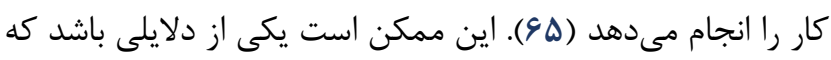
باغبانان هنكام كار احساس آرامش و خوشحالى مى كنند.

\section{كشتن باكترىهاى خوب خود را متوقف كنيد!}

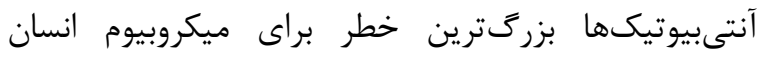

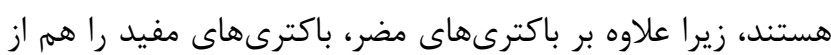
بين مىبرند. عوامل كمتر شناختهشده مانند استرس، داروهاى تجويزى، رزيم غذايى نامرغوب، شر ايط بهداشتى ضعيف و و استفادئ

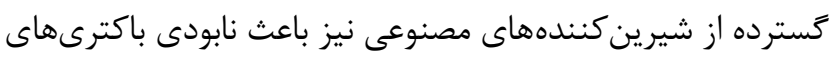

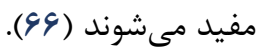


كونهها و ويزگ هاى ديكر آنها توجه شود. به طور مثال، برخى از

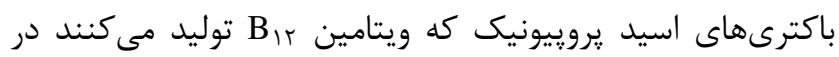

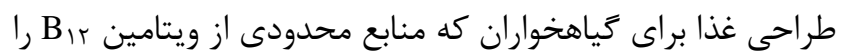
در اختيار دارند مىتواند استفاده شود.

\section{نتيجه}

جمعيت ميكروبى روده از بدو تولد تشكيل مىشود و از يك

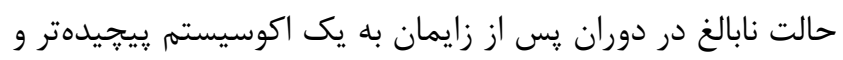

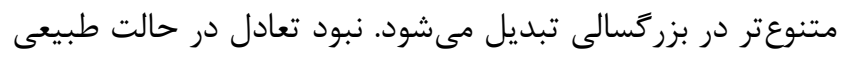

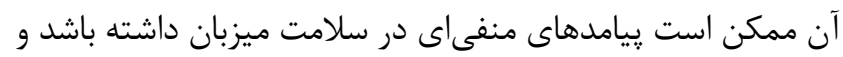

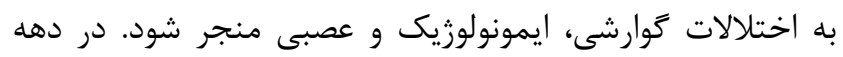
كذشته مطالعات متعددى در زمينهُ ارتباط بين اختلالات روانى و ورنائ

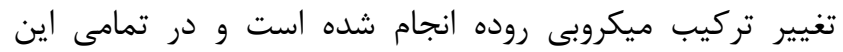

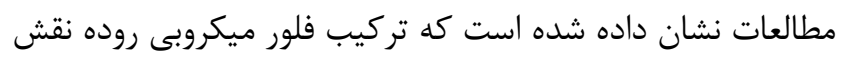
مهمى در سلامت روانى انسان دارد. با در نظر ترفتن اين موضوع

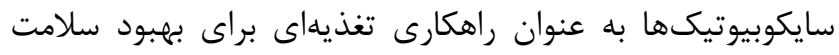

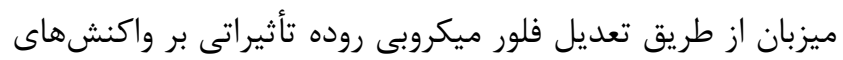

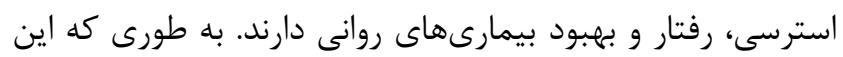

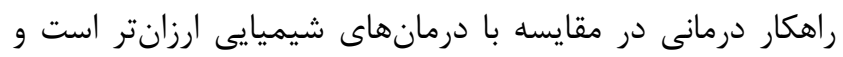

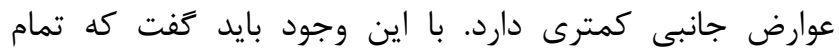

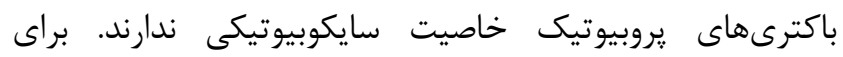

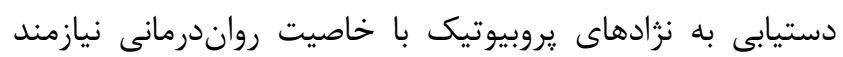
تحقيقات بيشترى روى مدل هاى حيوانى و در سطح بالينى هستيم

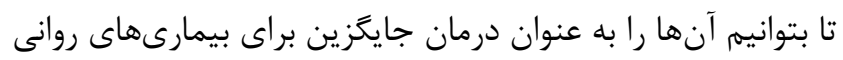
تأييد كنيم.

\section{سياسگزارى}

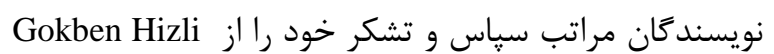
Mesut Cetin. Sayar بخشى از اين نوشتار استفاده شده است اعلام مى دارند.

$$
\text { تعارض منافع }
$$

بين نويسندكان تعارض در منافع كزارش نشده است.

\section{References}

1. Qin J, Li R, Raes J, Arumugam M, Burgdorf KS, Manichanh C. et al. A Human Gut Microbial Gene Catalogue Established by Metagenomic Sequencing. Nat. 2010; 464(7285): 59-65.

\section{توليد محصولات يروبيوتيك جديد}

علاوه بر محصولات تخميرى سنتى، محصولات يروبيوتيك ئن

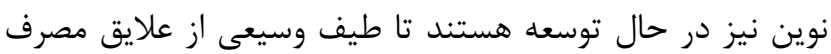

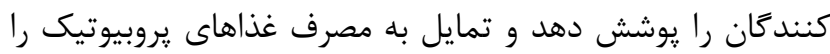
ترويج دهد. Rezaei و همكاران ( (اqس |) با به كاركيرى دو باكترى لاكتوباسيلوس اسيلوفيلوس (La5) و و بيفيدوباكتريوم لاكتيس (Bb12) ماست منجمد يروبيوتيك تهيه كردند و اثر صمغ عربى و و صمغ گوار را بر ميزان زندهمانى اين دو باكترى يروبيوتيك بررسى

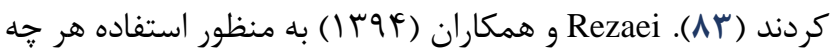
بيشتر از خواص سلامتىبخش ايزوفلاونهاى موجود در سويا، با استفاده از فيبرهاى بتاكلوكان و نشاسته مقاوم ماست سويا منجمد سينبيوتيك تحقيقى انجام دادند (AF). در اين مطالعه باكترىهاى اسيد لاكتيك يروبيوتيك از ل طريق بيوترانسفورماسيون، ايزوفلاونهايى را كه به طور طبيعى به شكل كليكوزيدى در سويا

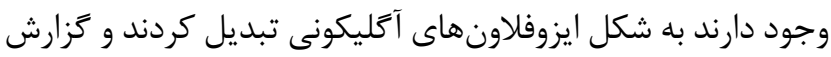

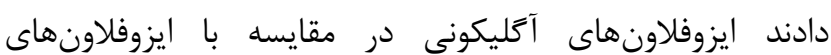

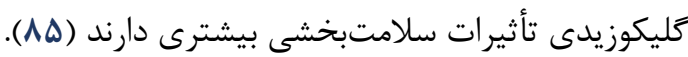
اغلب گونههاى بالقوه يروبيوتيك در شير بهخوبى رشد

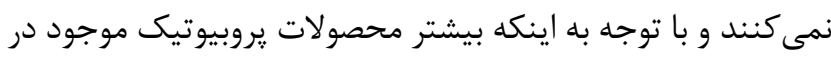
بازار بر پايه شير هستند، نكرانىهايى را در خصوص زندهمانى اين باكترىها تا زمان مصرف محصول ايجاد مى كند. از اينرو محققان تلاشهايى براى وارد كردن باكترىهاى يروبيوتيك به محصولات غيرلبنى صورت دادهاند كه در اين خصوص مى توان به توليد آبميوه يروبيوتيك و زيتون يروبيوتيك اشاره كرد (1)، \()). با افزايش تعداد افراد گياهخوار، تقاضا براى محصولات يروبيوتيكى گياهى نيز افزيوني

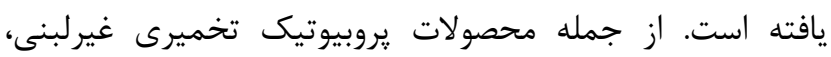
نوشيدنى هاى غيرلبنى تخميرى مانند بوزا (Boza)، بوشرا

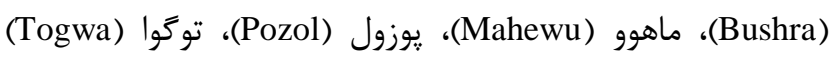
هستند كه در بيشتر اين محصولات از غلات به عنوان ماده خام اصلى استفاده مىشود. با اينكه امروزه در بين باكترىهاى : يروبيوتيك، باكترىهاى

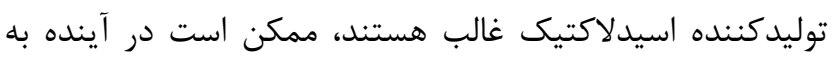

2. Geurts L, Neyrinck AM, Delzenne NM, Knauf C, Cani PD. Gut Microbiota Controls Adipose Tissue Expansion, Gut Barrier And Glucose Metabolism: Novel Insights Into Molecular Targets And Interventions Using Prebiotics. Benef Microbes. 2013; $1-15$. 
3. Chen X, D'souza R, Hong ST. The Role of Gut Microbiota in the Gut-Brain Axis: Current Challenges and Perspectives. Protein Cell. 2013; 4: 403-14.

4. Ostaff MJ, Stange EF, Wehkamp J. Antimicrobial Peptides and Gut Microbiota in Homeostasis and Pathology. EMBO Mol Med. 2013; 5: 1465-1483.

5. Honda K, Littman DR. The Microbiota in Adaptive Immune Homeostasis and Disease. Nat. 2016; 535: 75-84.

6. Penders J, Thijs C, Vink C. Factors Influencing the Composition of the Intestinal Microbiota in Early Infancy. Pediatrics. 2016; 118(2): 511-521.

7. Yatsunenko T, Rey FE, Manary MJ. Human Gut Microbiome Viewed Across Age and Geography. Nat. 2012; 486(7402):222-227.

8. Dinan TG, Cryan FJ. Brain-Gut-Microbiota Axis and Mental Health. Int J Behav Med. 2017; 79(8): 920926.

9. Grenham S, Clarke G,. Cryan J F, Dinan T G. BrainGut-Microbe Communication in Health And Disease. Front Physiol. 2011.

10. Kali A. Human Microbiome Engineering: The Future and Beyond. J Clin Diagn Res. 2015; 9(9).

11. Barrett E, Ross RP, O'Toole PW, Fitzgerald GF, Stanton C. Aminobutyric Acid Production by Culturable Bacteria From the Human Intestine. $\mathbf{J}$ of Appl Microbiol. 2012; 113: 411-7.

12. Dicks LMT. Botes M. Probiotic Lactic Acid Bacteria in the Gastro Intestinal Tract: Health Benefits, Safety and Mode of Action. Benef Microbes. 2010; 1(1): 1129.

13. O’Mahony SM, Clarke G, Borre YE, Dinan T, Cryan JF. Serotonin, Tryptophan Metabolism and the BrainGut-Microbiome Axis. Behav Brain Res. 2014; 277:32-48.

14. Wall R, Cryan JF, Ross RP, Fitzgerald GF, Dinan TG, Stanton C. Microbial Endocrinology: The MicrobiotaGut-Brain Axis in Health and Disease. 2014; 817, 221 239.

15. Dinan TG, Cryan FJ. Mood by Microbe: Towards Clinical Translation. Genome Med. 2013; 8:36.

16. Shahdadi F, Mirzaei H, Kashaninejad M, Khomeiri M, Ziaiifar AM, Akbarian A. Survival of Probiotics Encapsulated in Calcium Alginate and Resistant Starch Beads in Drinking Yoghurt Produced With Essential Oils During Storage and in Simulated Gastrointestinal Juice Conditions. Int J Biosci. 2014; 5(12): 58-71.

17. Vosough S, Khomeiri M, Kashaninejad M, Jafari M. Effect of Peppermint on Survival of Probiotic Bacteria in Iranian Traditional Beverage. J Agr Sci Nat Res. 2000; 16(1): 156-164.

18. Mokhtari S, Jafari M, Khomeiri M, Ghorbani M, Maghsoudlou M. The Cell Wall Compound of Saccharomyces Cerevisiae as a Novel Wall Material for Encapsulation of Probiotics. Food Res Int. 2017.

19. Hill C, Guarner F, Reid G, Gibson GR, Merenstein DJ, Pot B, et al. Expert Consensus Document: The International Scientific Association for Probiotics and Prebiotics Consensus Statement on the Scope and Appropriate Use of the Term Probiotic. Nat Rev Gastroenterol Hepatol. 2014; 11: 506-514.

20. Petschow B, Dore J, Hibberd P, Dinan T, Reid G, Blaser M. Probiotics, Prebiotics, and the Host Microbiome: The Science of Translation. Ann N Y Acad Sci. 2013; 1306: 1-17.

21. Tsilingiri K, Rescigno M. Postbiotics: What else? Benef Microbes. 2013;4(1):101-7.

22. Schrezenmeir J, de Vrese M. Probiotics, Prebiotics, and Synbiotics-Approaching a Definition. Am J Clin Nutr. 2001; 73, 361-364.

23. Rezaei R, Khomeiri M, Aalami M, Kashaninejad M. Steady and Dynamic Rheological Behaviour of Frozen Soy Yogurt Mix Affected by Resistant Starch and BGlucan. Int J Food Prop. 2017; 52: 8164.

24. Sayar GH, Mesut C. Psychobiotics: The Potential Therapeutic Promise of Microbes in Psychiatry. Klinik Psikofarmakol Bülteni. 2016; 26(2): 93-102.

25. Collins SM, Surette M, Bercik P. The Interplay Between the Intestinal Microbiota and the Brain. Nat Rev Microbiol. 2012; 10(11): 735-42.

26. Cong X, Henderson WA, Graf J, McGrath, JM. Early Life Experience and Gut Microbiome: The Brain-GutMicrobiota Signaling System; Advances in Neonatal Care. J Natio Assoc Neonatal Nurs. 2015; 15: 314.

27. Collins SM, Bercik, P. Gut Microbiota: Intestinal Bacteria Influence Brain Activity in Healthy Humans. Nat Rev Gastro Hepat. 2013; 10: 326-327.

28. Pract HN. Microbiota in Neuropsychiatry. Herbal and Nutritional Supplements. 2017; 31(4): 270-273.

29. Vilarrubias CB. Oh My Gut: Role of Gut Bacteria in Production of Neurochemical Compounds Influencing Mood and Behaviour in Humans. Clara Bullich Vilarrubias. 2015.

30. Clarke G, Grenham S, Scully P, Fitzgerald P, Moloney RD, Shanahan F. The Microbiome-Gut-Brain Axis During Early Life Regulates the Hippocampal Serotonergic System in a Sex-Dependent Manner. Mol Psychiatry. 2013; 18: 666-73. 


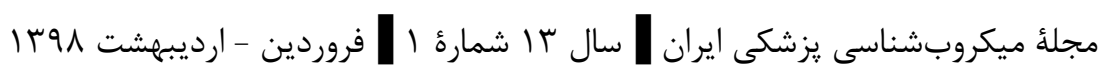

31. Evengård B, Schacterle RS, Komaroff AL. Chronic Fatigue Syndrome: New Insights and Old Ignorance. J Intern Med. 1999; 246(5): 455-469.

32. Lydiard RB, Falsetti SA. Experience with Anxiety and Depression Treatment Studies: Implications for Designing Irritable Bowel Syndrome Clinical Trials. Am J Med . 1999; 107(5A): 65-73.

33. Tiequn B, Guanqun C, Shuo Z. Therapeutic Effects of Lactobacillus in Treating Irritable Bowel Syndrome: A Metaanalysis. Inter Med. 2015; 54(3):243-9.

34. Logan AC, Wong C. Chronic Fatigue Syndrome: Oxidative Stress and Dietary Modifications. Altern Med Rev. 2001; 6(5): 450-9.

35. Rao AV, Bested AC, Beaulne TM, Katzman MA, Iorio C, Berardi JM. A Randomized, Double-Blind, Placebo-Controlled Pilot Study of A Probiotic in Emotional Symptoms of Chronic Fatigue Syndrome. Gut Pathog. 2009; 1(1).

36. Landa RJ. Diagnosis of Autism Spectrum Disorders in the First 3 Years of Life. Nat Clin Pract Neurol. 2008; 4(3): 138-47.

37. Reddy BL, Saier MH. Autism and Our Intestinal Microbiota. J Mol Microbiol Biotechnol. 2015; 25(1):51-5.

38. de Magistris L, Familiari V, Pascotto A, Sapone A, Frolli A, Iardino P. Alterations of the Intestinal Barrier in Patients With Autism Spectrum Disorders and in Their Firstdegree Relatives. J Pediatr Gastroenterol Nutr. 2010; 51(4): 418- 24.

39. Williams BL, Hornig M, Parekh T, Lipkin WI. Application of Novel PCR- Based Methods for Detection, Quantitation, and Phylogenetic Characterization of Sutterella Species in Intestinal Biopsy Samples From Children With Autism and Gastrointestinal Disturbances. MBio. 2012; 3(1): 26111.

40. Sandler RH, Finegold SM, Bolte ER, Buchanan CP, Maxwell AP, Vaisanen ML. Short-Term Benefit From Oral Vancomycin Treatment of Regressive-Onset Autism. J Child Neurol. 2000; 15(7): 429-35.

41. Parracho HM, Bingham MO, Gibson GR, McCartney AL. Differences Between the Gut Microflora of Children With Autistic Spectrum Disorders and That of Healthy Children. J Med Microbiol. 2005; 54(10): 987-91.

42. Davie CA. A Review of Parkinson's Disease. Brit Med Bull. 2008; 86 (1): 109-27.

43. Savica R, Carlin JM, Grossardt BR, Bower JH, Ahlskog JE, Maraganore DM. Medical Records Documentation of Constipation Preceding Parkinson Disease: A Case-Control Study. Neurol. 2009; 73(21): 1752-8.
44. Forsyth CB, Shannon KM, Kordower JH, Voigt RM, Shaikh M, Jaglin JA. Increased Intestinal Permeability Correlates With Sigmoid Mucosa Alpha-Synuclein Staining and Endotoxin Exposure Markers in Early Parkinson's Disease. PLOS One. 2011; 6(12): 28032.

45. Bangsgaard Bendtsen KM, Krych L, Sorensen DB, Pang W, Nielsen DS, Josefsen K. Gut Microbiota Composition is Correlated to Grid Floor Induced Stress and Behavior in the Balb/C Mouse. PLOS One. 2012; 7(10): 46231 .

46. Saulnier DM, Ringel Y, Heyman MB, Foster JA, Bercik P, Shulman RJ. The Intestinal Microbiome, Probiotics and Prebiotics in Neurogastroenterology. Gut Microbes. 2013; 4(1): 17-27.

47. Drescher LS, Thiele S, Mensink GB. A New Index to Measure Healthy Food Diversity Better Reflects a Healthy Diet Than Traditional Measures. J Nutr. 2007; 137(3): 647-51.

48. Naseribafrouei A, Hestad K, Avershina E, Sekelja M, Linlokken A, Wilson R. Correlation Between the Human Fecal Microbiota and Depression. J Neurogastroenterol Motil. 2014; 26(8): 1155-62.

49. Katano Y, Fujinami S, Kawakoshi A, Nakazawa H, Oji S, Ino T. Complete Genome Sequence of Oscillibacter Valericigenes. Stand Genomic Sci. 2012; 6(3): 406-14.

50. Ortiz JG, Nieves-Natal J, Chavez P. Effects of Valeriana Officinalis Extracts on [3h] Flunitrazepam Binding, Synaptosomal [3h] Gaba Uptake, and Hippocampal [3h] Gaba Release. Neurochem Res. 1999; 24(11): 1373-8.

51. Ledochowski M, Sperner-Unterweger B, Fuchs D. Lactose Malabsorption is Associated With Early Signs of Mental Depression in Females: A Preliminary Report. Dig Dis Sci. 1998; 43(11): 2513-7.

52. Montalto M, Curigliano V, Santoro L, Vastola M, Cammarota G. Manna, R. Management and Treatment of Lactose Malabsorption. World J Gastroenterol. 2006; 12(2): 187-91.

53. Ledochowski M, Widner B, Murr C, SpernerUnterweger B, Fuchs D. Fructose Malabsorption is Associated With Decreased Plasma Tryptophan. Scand J Gastroenterol. 2001; 36(4): 367-71.

54. Taki K, Takayama F, Niwa T. Beneficial Effects of Bifidobacteria in A Gastroresistant Seamless Capsule on Hyperhomocysteinemia in Hemodialysis Patients. J Ren Nutr. 2005; 15(1):77-80.

55. Desbonnet L, Garrett L, Clarke G, Kiely B, Cryan JF, Dinan TG. Effects of the Probiotic Bifidobacterium Infantis in the Maternal Separation Model of Depression. J Neurosci. 2010; 170(4): 1179-88.

56. Perez-Burgos A, Wang B, Mao YK, Mistry B, McVey Neufeld KA, Bienenstock J. Psychoactive Bacteria 
Lactobacillus Rhamnosus (JB-1) Elicits Rapid Frequency Facilitation in Vagal Afferents. Am J Physiol Gastrointest Liver Physiol. 2013; 304(2): G211-20.

57. Madsen KL. Interactions Between Microbes and the Gut Epithelium. J Clin Gastroenterol. 2011; 45(Suppl.): 111-4.

58. Meijerink M, Mercenier A, Wells JM. Challenges in Translational Research on Probiotic Lactobacilli: From In Vitro Assays to Clinical Trials. Benef Microbes. 2013; 4(1):83-100.

59. Larsen CN, Nielsen S, Kaestel P, Brockmann E, Bennedsen M, Christensen HR. Dose-Response Study of Probiotic Bacteria Bifidobacterium Animalis Subsp Lactis Bb-12 and Lactobacillus Paracasei Subsp Paracasei Crl-341 in Healthy Young Adults. Eur J Clin Nutr. 2006; 60(11): 1284-93.

60. Collins SM, Kassam, Z Bercik P. The Adoptive Transfer of Behavioral Phenotype Via the Intestinal Microbiota: Experimental Evidence and Clinical Implications. Curr Opin Microbiol. 2013; 16(3): 2405.

61. Li YT, Cai HF, Wang ZH, Xu J, Fang JY. Systematic Review with Meta-Analysis: Long-Term Outcomes of Faecal Microbiota Transplantation for Clostridium Difficile Infection. Aliment Pharm Ther. 2016; 43(4): 445-57.

62. Bourlioux P. Workgroup of the French Academy of Pharmacy. Faecal Microbiota Transplantation: Key Points to Consider. Ann Pharm Fr. 2015; 73(3): 1638.

63. Altay F, Karbancioglu-Guler F, Daskaya-Dikmen C. Heperkan DA. A Review on Traditional Turkish Fermented Nonalcoholic Beverages: Microbiota, Fermentation Process and Quality Characteristics. Int J Food Microbiol. 2013; 167(1): 44-56.

64. Homayouni A, Akbarzadeh F, Vaghef-Mehrabani E. Which Are More Important: Prebiotics or Probiotics? Nutr. 2012; 28(11-12): 1196-7.

65. Lowry CA, Hollis JH, de Vries A, Pan B, Brunet LR, Hunt JR, Paton JF, van Kampen E, Knight DM, Evans AK, Rook GA, Lightman SL. Identification of an immune-responsive mesolimbocortical serotonergic system: potential role in regulation of emotional behavior. Neuroscience. 2007; 146:756-772.

66. Shell E. Artificial Sweeteners Get a Gut Check. Sci Am. 2015; 312(4): 32-34.

67. Rattray FP, O’Connell MJ. Fermented Milks Kefir. In: Fukay JW, ed. Encyclopedia of Dairy Sciences. $2^{\text {th }}$ ed. San Diego: Academic Press; 2011; 518-524.
68. Rodrigues KL, Caputo LR, Carvalho JC, Evangelista J, Schneedorf JM. Antimicrobial and Healing Activity of Kefir and Kefiran Extract. Int J Antimicrob Agents. 2005; 25(5): 404-8.

69. Guven A, Guven A, Gulmez M. The Effect of Kefir on the Activities of GSH-Px, GST, CAT, GSH and LPO Levels in Carbon Tetrachloride-iInduced mMice Tissues. J Vet Med B Infect Dis Vet. 2003; 50(8): 4126.

70. Soleimani B, Khomeiri M, Sadeghi A. Fermentation of Camel Milk Using Industrial Starter Culture and Isolates From Chal and Study of Product Changes During Storage Time. Gorgan: Gorgan University of Agricultural Sciences and Natural Resources, M.C. Faculty of Food Sciences and Technology; 2017 [in Persian].

71. Pouramini N, Khomeiri M, Khodaiyan F, Mohamaddifar M, Maghsoudlou Y. Study of Lowering Effect of Prebiotic in Probiotic Media Culture and Their Effect o Probiotic Yogurt Properties. Gorgan: Gorgan University of Agricultural Sciences and Natural Resources, M.C. Faculty of Food Sciences and Technology; 2000 [in Persian].

72. Medrano M, Racedo SM, Rolny IS, Abraham AG, Perez PF. Oral Administration of Kefiran Induces Changes in the Balance of Immune Cells in A Murine Model. J Agric Food Chem. 2011; 59(10): 5299-304.

73. Bravo JA, Forsythe P, Chew MV, Escaravage E, Savignac HM, Dinan TG, et al. Ingestion of Lactobacillus Strain Regulates Emotional Behavior and Central Gaba Receptor Expression in A Mouse Via The Vagus Nerve. Proc Natl Acad Sci USA. 2011; 108(38): 16050-16055.

74. Yam BZ, Khomeiri M, Mahounak AS, Jafari SM. Isolation and Identification of Yeasts and Lactic Acid Bacteria from Local Traditional Fermented Camel Milk, Chal. J Food Proc Technol. 2015; 6: 460.

75. Yolmeh M, Khomeiri M, Ahmadi Z. Application of Mixture Design to Introduce an Optimum Cell-Free Supernatant of Multiple-Strain Mixture (MSM) For Lactobacillus Against Food-Borne Pathogens. LWT Food Sci Tech. 2017; 83: 298-304.

76. Ahmadi M, Khomeiri M, Khosroshahi A, Kashaninejad M. Isolation and Identification of Lactic Flora of Traditional Lighvan Cheese. 2000. Eighth National Congress [in Persian].

77. Shoori S, Khomeiri M, Maghsoudlou Y, Sadeghi A. Evaluation of Probiotic and Antagonistic Properties of Some Lactic Acid Bacteria Isolated From Lighvan Cheese and Chal. Gorgan University of Agricultural Sciences and Natural Resources, M.C. Faculty of Food Sciences and Technology; 2012 [in Persian]. 


$$
\text { مجلهُ ميكروبشناسى يزشكى ايران [ سال س| شماره | [ فروردين - ارديبهشت }
$$

78. Khomeiri M, Mortazavi A, Ghodousi B, Khamesan A, Derakhshan A, Shahidi F. Identification of Bifidobacterium Isolated Fecial Samples in Iran Using PCR With Specific Genus Primers and 16SRRNA Sequence Analysis. J Keramn Uni Med Sci. 2004; 12(1):21-31.

79. Su Oh N, Joung JY, Lee JY, Younghoon K. Probiotic and Anti-Inflammatory Potential of Lactobacillus Rhamnosus 4b15 and Lactobacillus Gasseri $4 \mathrm{~m} 13$ Isolated From Infant Feces. PLOS One. 2018; 13(2): e0192021.

80. Klopper KB, Deane SM, Dicks LMT. Aciduric Strains of Lactobacillus Reuteri and Lactobacillus Rhamnosus, Isolated From Human Feces, Have Strong Adhesion and Aggregation Properties. Probiotics and Antimicrob Proteins. 2018; 10(1): 8997.

81. Gheziel C, Russo P, Arena MP, Spano G, Ouzari HI, Kheroua O, et al. Evaluation the Probiotic Potential of Lactobacillus Plantarum Strains From Algerian Infant Feces: Toward the Design of Probiotic Starter Cultures Tailored for Developing Countries. Probiotics Antimicrob Proteins. 2018; 1-11.

82. Martin R, Miquel S, Benevides L, Bridonnrau C, Robert V, Hudault S, et al. Functional characterization of Novel Faecalibacterium Prausnitzii Strains Isolated From Healthy Volunteers: a Step Forward in the Use of f. Prausnitzii as a Next Generation Probiotic. Front Microbiol. 2017; 8: 1226.

83. Rezaei R, Khomeiri M, Aalami M, Kashaninejad M. Effect of Arabic Gum and Guar Gum on Viability of Lactobacillus Acidophilus (LA5) and Bifidobacterium Lactis (Bb12) in Frozen Probiotic Yogurt. Iran Food Sci Tech J. 2015; 8(4)

84. Rezaei R, Khomeiri M, Kashaninejad M. Production of Synbiotic Frozen Soy-Yogurt and Evaluation of its Isoflavone Transformation. Gorgan University of Agricultural Sciences and Natural Resources, PhD. Faculty of Food Sciences and Technology. 2012.

85. Chen KI, Erh MH, Su NW, Liu WH, Chou CC, Cheng KC. Soy Foods and Soybean Products: From Traditional Use to Modern Application. Appl Microbiol Biotechnol. 2012; 96:9-22.

86. Ahmadi Z, Khomeiri M, Sadeghi A, Maghsoudlou Y. Iaolation and Identification of Dominant Microflora of Fermented Olive and its Usage in Production of Processed Olive. Gorgan University of Agricultural Sciences and Natural Resources, MSc. Faculty of Food Sciences and Technology. 2015.

87. Nagatsu T, Nagatsu I. Tyrosine Hydroxylase (TH), its Cofactor Tetrahydrobiopterin (BH4), Other Catecholamine-Related Enzymes, and Their Human Genes in Relation to the Drug and Gene Therapies of Parkinson's Disease (PD): Historical Overview and Future Prospects. J Neural Transm. 2016; 123. 